Journal

of

Hydrology

www.elsevier.com/locate/jhydrol

\title{
Nutrient inputs to the coastal ocean through submarine groundwater discharge: controls and potential impact
}

\author{
Caroline P. Slomp*, Philippe Van Cappellen \\ Department of Earth Sciences-Geochemistry, Faculty of Geosciences, Utrecht University, \\ P.O. Box 80021, 3508 TA Utrecht, The Netherlands
}

Received 12 September 2003; revised 2 February 2004; accepted 16 February 2004

\begin{abstract}
Nutrient input through submarine groundwater discharge (SGD) rivals river inputs in certain regions and may play a significant role in nutrient cycling and primary productivity in the coastal ocean. In this paper, we review the key factors determining the fluxes of nitrogen $(\mathrm{N})$ and phosphorus $(\mathrm{P})$ associated with SGD and present a compilation of measured rates. We show that, in particular, the water residence time and the redox conditions in coastal aquifers and sediments determine fluxes and ratios of $\mathrm{N}$ and $\mathrm{P}$ in SGD. In many coastal groundwater systems, and especially in contaminated aquifers, N/P ratios exceed those in river water and are higher than the Redfield ratio. Thus, anthropogenically driven increases in SGD of nutrients have the potential to drive the $\mathrm{N}$-limited coastal primary production to P-limitation. River input of $\mathrm{N}$ and $\mathrm{P}$ to the coastal ocean has doubled over the past $50 \mathrm{yr}$. Results of a dynamic biogeochemical model for the $\mathrm{C}, \mathrm{N}$ and $\mathrm{P}$ cycles of the global proximal coastal ocean (which includes large bays, the open water part of estuaries, deltas, inland seas and salt marshes), suggest that this has led to a factor 2 increase in primary production and biomass and a decline in water column N/P ratios, i.e. the system has

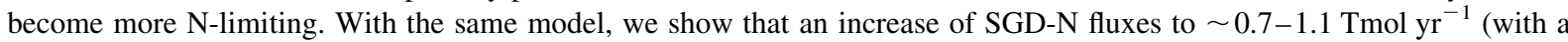
SGD N/P ratio of 100; equal to $\sim 45-70 \%$ of pre-human riverine $\mathrm{N}$-inputs) is required to drive the coastal ocean to P-limitation within the next $50 \mathrm{yr}$.

(C) 2004 Elsevier B.V. All rights reserved.
\end{abstract}

Keywords: Nitrogen; Phosphorus; Submarine groundwater discharge

\section{Introduction}

Submarine groundwater discharge (SGD) is a potentially important but as yet poorly quantified source of nutrients to the coastal ocean (Burnett et al., 2001; Johannes, 1980; Moore, 1999; Simmons, 1992). Accurate insight into the magnitude

\footnotetext{
* Corresponding author.

E-mail address: slomp@geo.uu.nl (C.P. Slomp).
}

and controls of nitrogen (N) and phosphorus (P) fluxes associated with SGD is needed if we want to understand how the coastal ocean functions and how it responds to anthropogenic or natural perturbations (Mackenzie et al., 2002; Rabouille et al., 2001; Ver et al., 1999b). Continued residential and agricultural development of near-shore areas worldwide, for example, is leading to increased inputs of $\mathrm{N}$ and $\mathrm{P}$ from fertilizer and wastewater to groundwater, 
and part of these nutrients are released to coastal surface waters (Valiela et al., 1990). Increased saltwater intrusion in coastal, freshwater aquifers due to groundwater mining and sea level rise may further enhance the SGD fluxes of $\mathrm{N}$ and $\mathrm{P}$ through ion exchange and other reactions (Krest et al., 2000; Moore, 1999).

The $\mathrm{N}$ and $\mathrm{P}$ concentrations in coastal groundwater are often much higher than those in river water, compensating for the lower mass flux of groundwater relative to surface water (Moore, 1999; Valiela et al., 1990). Apart from the amounts of $\mathrm{N}$ and $\mathrm{P}$ entering the coastal ocean through SGD, it is also important to evaluate the potential effect of SGD on the ratio of $\mathrm{N}$ and $\mathrm{P}$ in coastal waters, because this ratio determines which nutrient is limiting phytoplankton growth (Howarth, 1988). The flux ratio of dissolved inorganic nitrogen (DIN) and dissolved inorganic phosphorus (DIP) in rivers is variable and ranges over two orders of magnititude (Caraco, 1995; Kempe, 1984; Meybeck, 1993). On a global scale, however, the average molar ratio is 18:1 (Meybeck, 1982; Smith et al., 2003), and thus closely matches the requirements of phytoplankton $(\mathrm{N}: \mathrm{P}=16: 1$, which is the 'Redfield ratio'). Water column DIN/DIP ratios in coastal areas are generally below Redfield and this is generally attributed to enhanced recycling of $\mathrm{P}$ relative to $\mathrm{N}$ (Howarth, 1988; Nixon et al., 1980). Mobilization of nutrients from reactive riverine particulates with N/P ratios below Redfield could also play a role. As a consequence of the below Redfield water column DIN/DIP ratio, coastal ecosystems are generally N-limited (Conley, 2000; Howarth, 1988; Nixon et al., 1980). Groundwater DIN/DIP ratios in contaminated aquifers are typically much higher than 18 , because $\mathrm{P}$ in groundwater is more efficiently immobilized than $\mathrm{N}$ (Lapointe et al., 1990; Weiskel and Howes, 1992). Potentially, increased nutrient inputs through SGD may therefore, drive N-limited coastal systems towards P-limitation (Paerl, 1997; Valiela et al., 1990; Weiskel and Howes, 1992).

In this paper, we first review the key factors determining the SGD flux of $\mathrm{N}$ and $\mathrm{P}$ to coastal waters and present a compilation of measured SGD associated $\mathrm{N}$ and $\mathrm{P}$ fluxes. We then discuss the potential effects of $\mathrm{N}$ and $\mathrm{P}$ inputs through SGD to the coastal ocean on a regional scale and demonstrate its potential importance on a global scale using a process-based, dynamic biogeochemical model.

\section{Controls on the SGD flux of $\mathbf{N}$ and $\mathbf{P}$ to coastal waters}

The primary factors controlling the flux of $\mathrm{N}$ and $\mathrm{P}$ through coastal aquifers and sediments to coastal waters are (1) the flow paths and rates of the groundwater as these determine the residence time and extent of contact with the aquifer solids, (2) the supply rate and form of $\mathrm{N}$ and $\mathrm{P}$ from natural or anthropogenic sources, and (3) the redox conditions in the subsurface, which strongly affect the transformation processes and mobility of $\mathrm{N}$ and $\mathrm{P}$.

\subsection{Hydrology of coastal aquifers and occurrence of $S G D$}

Coastal aquifers can be classified, depending on their hydrology, as shallow (local flow system) or deep (intermediate or regional flow systems)(Toth, 1963) Shallow aquifers typically have high rates of recharge $\left(1-30 \mathrm{~cm} \mathrm{yr}^{-1}\right)$ and high rates of groundwater flow $\left(1-100 \mathrm{~m} \mathrm{yr}^{-1}\right)$. Rates of recharge and water levels respond rapidly to individual precipitation events. Deep aquifers are much less connected with the surface and rates of recharge $\left(0.01-1 \mathrm{~cm} \mathrm{yr}^{-1}\right)$ and groundwater flow velocities $\left(0.1-1 \mathrm{~m} \mathrm{yr}^{-1}\right)$ are generally lower (Lovely and Chapelle, 1995).

SGD requires a hydraulic connection and a positive pressure gradient between shallow or deep coastal aquifers and the sea and occurs mainly as diffuse seepage along the shoreline, offshore seepage or spring discharge (Fig. 1). Near-shore diffuse seepage is typical for shallow, unconsolidated, coarse-grained aquifers, found, for example, in the glacial deposits along the NE coast of the USA (Portnoy et al., 1998; Valiela et al., 1990) or in the sand, clay and limestone mixtures of shallow aquifers in Florida (Cable et al., 1997a). The magnitude of this type of seepage generally decreases with increasing water depth and distance from the coast (Bokuniewicz, 1980; Cable et al., 1997a; Cooper, 1959; Giblin and Gaines, 1990; Lewis, 1987; Taniguchi et al., 2002). Offshore seepage due to a breach in a confining layer 


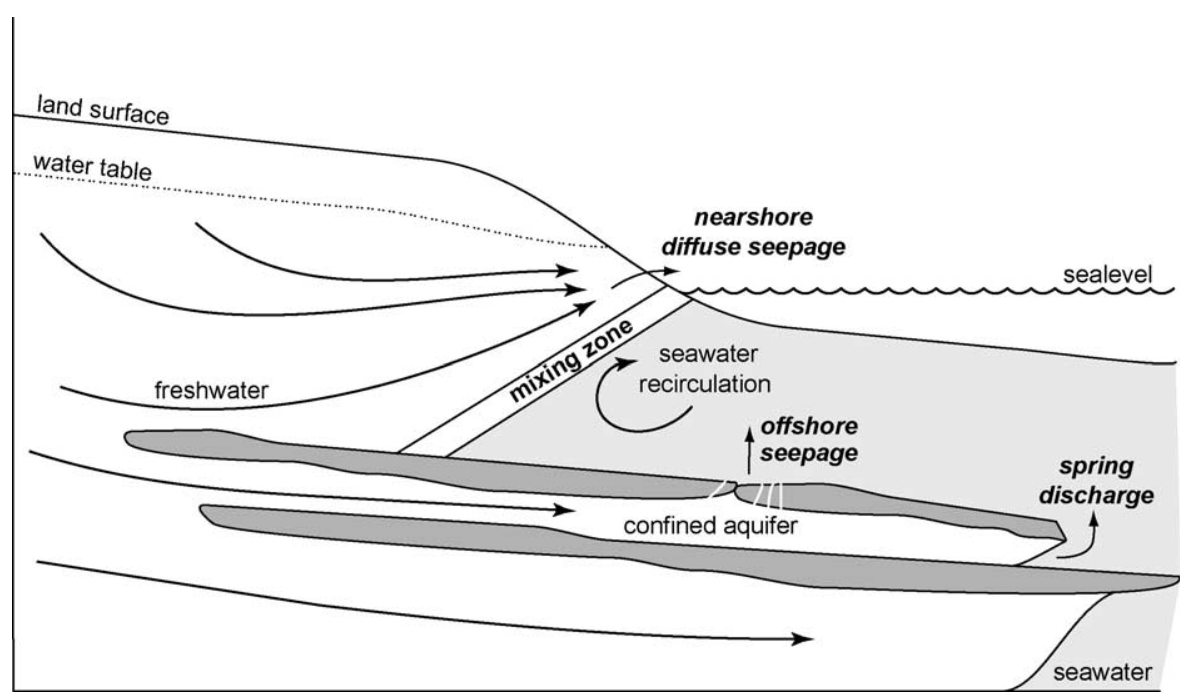

Fig. 1. Schematic overview of the relationship between shallow and deep coastal aquifers, seawater and the different types of SGD (diffuse seepage, offshore seepage, submarine springs) at the land-ocean interface (not to scale). Modified from Burnett et al. (2001).

or discharge from submarine springs is particularly important for karstic groundwater systems (D'Elia et al., 1981; Fetter, 1994). Typical examples are aquifers in Florida (Bugna et al., 1996; Cable et al., 1996a; Swarzenski et al., 2001), South Carolina (Moore and Shaw, 1998), the Yucatan Peninsula (Herrera-Silveira and Comin, 1995), the west coast of Australia (Johannes, 1980) and aquifers on carbonate islands such as Bermuda (Simmons and Lyons, 1994) and Jamaica (D'Elia et al., 1981).

On a local scale, SGD is often difficult to separate from density- or tidally driven seawater recirculation (Bokuniewicz and Pavlik, 1990; Li et al., 1999; Riedl et al., 1972; Simmons, 1992). It is generally determined by measuring the water accumulation in a plastic bag connected to a seepage chamber (Cable et al., 1997b; Lee, 1977), but more sophisticated automated seepage meters, based for example on temperature flow, are now also available (Taniguchi and Fukuo, 1993). Direct seepage measurements along shorelines indicate a large spatial and temporal variability of SGD (Burnett et al., 2001), with the highest rates generally occurring at sites at low tide and at sites with highly permeable sediments (Lewis, 1987; Portnoy et al., 1998; Taniguchi, 2002). SGD rates from shallow aquifers may also vary seasonally due to changes in precipitation (Cable et al., 1997a; Capone and Slater, 1990).
Independent quantitative information on the magnitude of SGD on a regional scale has been obtained from water balance, hydrological and tracer studies (Burnett et al., 2003, 2001; Moore, 1996; Younger, 1996). Suitable natural tracers include $\mathrm{Ra}$ isotopes (Charette et al., 2001; Hussain et al., 1999; Krest and Harvey, 2003; Krest et al., 1999, 2000; Moore, 1996; Moore and Shaw, 1998), Ba (Moore and Shaw, 1998; Shaw et al., 1998), ${ }^{222} \mathrm{Rn}$ (Cable et al., 1996b; Corbett et al., 2000; Top et al., 2001), $\mathrm{CH}_{4}$ (Bugna et al., 1996; Cable et al., 1996a) and the concentration and carbon isotopic composition of DIC (Gramling et al., 2003). The importance of SGD on a regional scale ranges from an insignificant contribution to almost $100 \%$ of the total water flux (Taniguchi et al., 2002). It strongly depends on topography, the presence and development of rivers, aquifer size, permeability and recharge through rainfall (Cable et al., 1997a). Karstic limestone and alluvial aquifers typically have high permeabilities and are expected to have the highest potential for SGD.

A compilation of world-wide SGD seepage measurements (Taniguchi et al., 2002) shows that rates range from 0.03 to $454 \mathrm{~m} \mathrm{yr}^{-1}$ but mostly fall below $36 \mathrm{~m} \mathrm{yr}^{-1}$. Measured discharge rates are often higher than average areal recharge rates, which is in line with the typically localized nature of SGD and the inclusion of seawater recycling. Shallow aquifers are 
probably more important as a source of groundwater for SGD than deep, confined aquifers, due to the more limited discharge points of the latter (Cable et al., 1997a; Lovely and Chapelle, 1995). Current estimates of the global flux of ground water entering the ocean through SGD vary widely, ranging from 0.01 to $10 \%$ of the surface water runoff (Church, 1996; Garrels and Mackenzie, 1971; Taniguchi et al., 2002; Zektser and Loaiciga, 1993). Our best estimate is $5 \%$ of the total global water flux or $1.85 \mathrm{Tm}^{3} \mathrm{yr}^{-1}$.

\subsection{Groundwater redox chemistry}

Most uncontaminated groundwater systems have a relatively limited internal reducing capacity Aquifer sediments generally contain only small amounts of reactive solid organic matter (Hartog et al., 2004), and organic matter decomposition is limited mainly by the amount and reactivity of infiltrating soil dissolved organic matter (DOC) that survives transport through the vadose zone (Pabich et al., 2001; Starr and Gillham, 1993). Shallow pristine aquifers with short residence times (high recharge and flow rates) and low soil water DOC concentrations may remain largely oxic (Fig. 2A). In shallow or deep (intermediate or regional aquifers) with longer residence times and/or higher DOC inputs, dissolved oxygen is usually entirely consumed and organic matter decomposition proceeds via denitrification, $\mathrm{Mn}$ and $\mathrm{Fe}$ oxide reduction, sulfate reduction and, ultimately, methanogenesis (Hansen et al., 2001; Jakobsen and Postma, 1999; Lovely and Chapelle, 1995). As a result, the aquifer becomes progressively more reducing along the direction of groundwater flow (Chapelle, 2001; Hunter et al., 1998; Murphy and Schramke, 1998). The organic matter accompanying inputs from manure and on-site sewage systems is usually degraded in the vadose zone and does not reach the groundwater (Richards and Webster, 1999; Wilhelm et al., 1994). Organic matter decomposition in sewage and fertilizer plumes in the saturated zone is therefore generally electron-donor limited and the redox sequence is often similar to that of uncontaminated aquifers (Fig. 2A).

As a result of DOC oxidation, discharging groundwater may be depleted in $\mathrm{NO}_{3}$ and enriched in reduced metabolites. Groundwaters with high concentrations of dissolved $\mathrm{Fe}^{2+}$ are common
(Appelo and Postma, 1993; Chapelle and Lovley, 1992). Discharge of this groundwater to soils in lowlying regions, or to sediments of inland or coastal waters can lead to the formation of iron oxide rich layers at the anoxic/oxic interface (Charette and Sholkovitz, 2002; Griffioen, 1994). Some coastal aquifers are strongly reduced and contain $\mathrm{CH}_{4}$ and $\mathrm{H}_{2}$, in addition to $\mathrm{NH}_{4}$ and $\mathrm{PO}_{4}$ (Bugna et al., 1996; Nyvang, 2003).

Rates of organic matter decomposition in uncontaminated deep aquifers $\left(10^{-8}-10^{-2} \mathrm{mmol} \mathrm{CO}_{2}\right.$ $\mathrm{dm}^{-3} \mathrm{yr}^{-1}$ ) determined through geochemical modeling are comparable to rates observed in highly oligotrophic deep ocean waters but are generally slower than those in modern deep-sea or lake sediments $\left(10^{-2}-10^{1} \mathrm{mmol} \mathrm{CO}_{2} \mathrm{dm}^{-3} \mathrm{yr}^{-1}\right)$ (Lovely and Chapelle, 1995; Murphy and Schramke, 1998). Rates in oxic shallow aquifers are not well quantified, but probably fall within the higher part of the range given for deep aquifers and the lower part of the range for sediments. Groundwater systems that are contaminated with organic matter (e.g. landfill leachate plumes) generally are electron-acceptor limited and are most reducing near the organic matter source (Chapelle, 2001; Christensen et al., 2000; Murphy and Schramke, 1998).

Aquifer solids from marine or fluvial origin often contain discrete accumulations of solid phase organic matter with minerals such as pyrite, siderite and $\mathrm{Fe}$ (II) silicates, which can act as a reductant when brought into contact with a suitable oxidant such as oxygen or nitrate (Appelo and Postma, 1993; Engesgaard and Kipp, 1992; Hartog et al., 2002; Postma et al., 1991). The geological history of the aquifer sediments strongly determines the amounts of these reductants, while environmental conditions such as $\mathrm{pH}$ and microbial activity are important in controlling their reactivity (Hartog et al., 2002; Schippers and Jorgensen, 2002).

\subsection{Nitrogen and phosphorus in groundwater}

$\mathrm{N}$ and $\mathrm{P}$ concentrations in groundwater are variable and depend on inputs, soil and aquifer type, aquifer permeability, groundwater recharge rate and climate (Nolan and Stoner, 2000; Tiessen, 1995) The main anthropogenic sources of $\mathrm{N}$ and $\mathrm{P}$ to groundwater are commercial fertilizer, manure and wastewater 

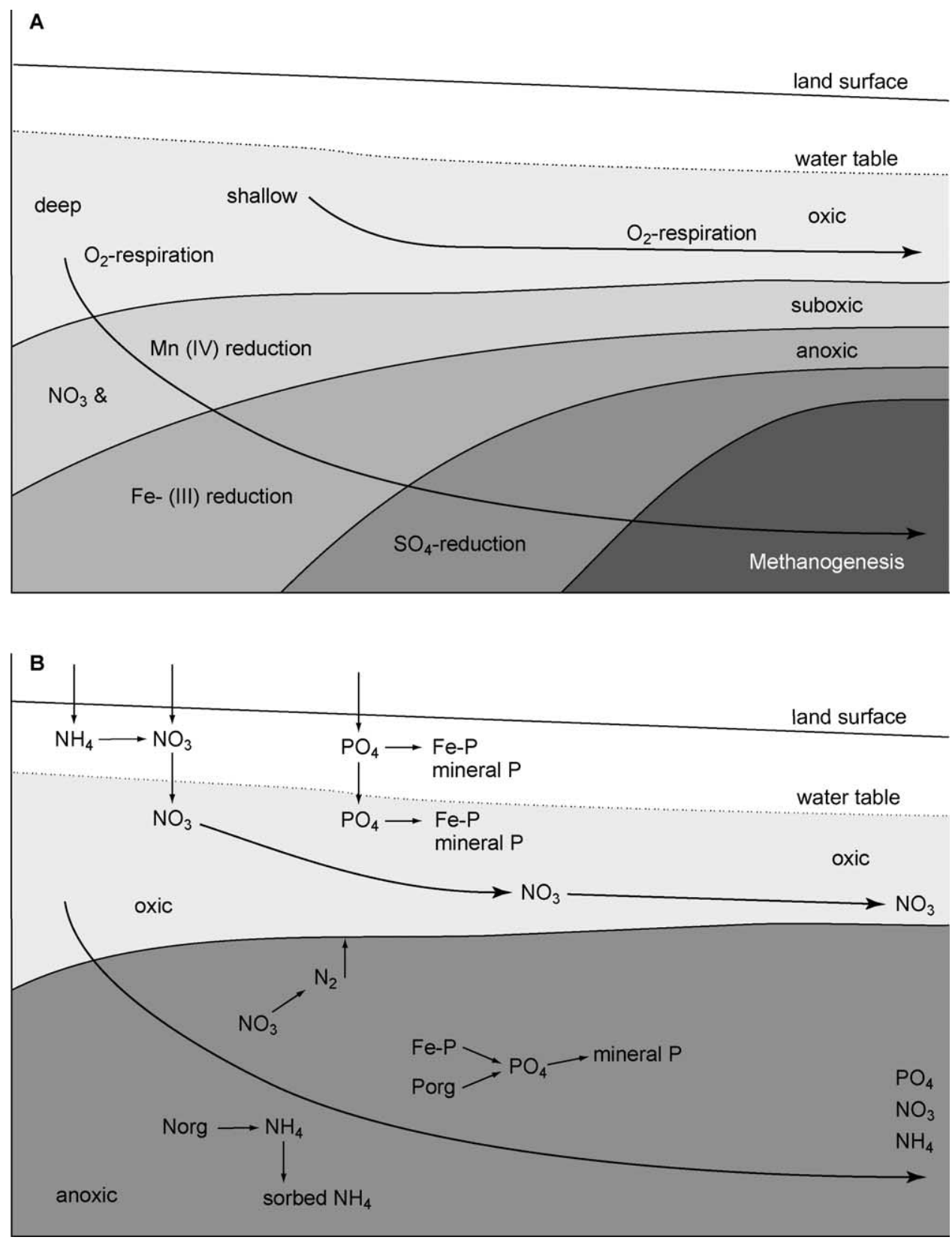

Fig. 2. (A) Schematic representation of the organic matter decomposition pathways in two end-member systems with low DOC input: a shallow aquifer with a short residence time and a deep aquifer with a long residence time. (B) Schematic representation of the processes affecting $\mathrm{N}$ and $\mathrm{P}$ in oxic and anoxic aquifers.

(including on-site sewage systems) (Appelo and Postma, 1993; Tiessen, 1995) (Fig. 2B). Atmospheric deposition is an additional source of $\mathrm{N}$ (Berner and Berner, 1996; Seitzinger and Kroeze, 1998; Tiessen,
1995). Natural inputs of $\mathrm{N}$ and $\mathrm{P}$ to groundwater are smaller and can involve downward leaching of $\mathrm{N}$ and $\mathrm{P}$ released from soil organic matter, in situ release from organic matter in the aquifer and, for $\mathrm{P}$, release 
from Fe-oxides under anoxia (Carlyle and Hill, 2001) and weathering of mineral phases (Dillon and Kirchner, 1975; Grobler and Silberbauer, 1985).

The highest dissolved $\mathrm{N}$ and $\mathrm{P}$ concentrations are typically found in shallow groundwater below agricultural land and in sewage plumes. The median groundwater $\mathrm{NO}_{3}$ concentration below cropland in the US is, for example, equal to $243 \mu \mathrm{M}$, while concentrations in pristine, deep aquifers are typically on the order of $30 \mu \mathrm{M} \mathrm{NO}_{3}$ (Nolan and Stoner, 2000). Concentrations above the maximum contaminant level of $10 \mathrm{mg} \mathrm{N} / \mathrm{l}$ (United States Environmental Protection Agency, 1995), which is equivalent to $714 \mu \mathrm{MN}$, are not uncommon. The median $\mathrm{PO}_{4}$ concentration for US groundwater is below $1 \mu \mathrm{M}$, and concentrations rarely exceed $6 \mu \mathrm{M}$ (Nolan and Stoner, 2000). Concentrations in sewage plumes vary, but can be as high as $2360 \mu \mathrm{M} \mathrm{NO} \mathrm{NO}_{3}$ and $150 \mu \mathrm{M} \mathrm{PO}_{4}$ (Robertson, 1995). Little is known about concentrations of dissolved organic $\mathrm{N}$ (DON) and dissolved organic P (DOP) in groundwater and how they may be affected by human impact. The limited studies carried out for soils suggest that $\mathrm{N}$ and $\mathrm{P}$ fertilization may increase DON and DOP concentrations, particularly in soils with low sorption capacities (Kalbitz et al., 2000; McDowell, 2003; Qualls and Richardson, 2003).

Groundwater $\mathrm{N}$ from anthropogenic sources is generally supplied in the form of $\mathrm{NO}_{3}$, since $\mathrm{NH}_{4}$ is nitrified in the unsaturated, oxic zone (Fig. 2B) (Jordan et al., 1997; Wilhelm et al., 1994). Substantial amounts of groundwater $\mathrm{NH}_{4}$ are only observed in aquifers, where $\mathrm{NH}_{4}$-rich wastewater is directly released into the saturated, anoxic zone (Ceazan et al., 1989), or when significant organic matter decomposition occurs under anoxic conditions, e.g. in land-fill leachate plumes (Brun et al., 2002; Christensen et al., 2001) or in aquifers naturally rich in organic matter.

Denitrification, the anaerobic microbial respiratory pathway in which $\mathrm{NO}_{3}$ is converted to $\mathrm{N}_{2}$, is the predominant removal process for groundwater $\mathrm{N}$ (Fig. 2B). Denitrification requires anoxia and an electron donor, which can be organic carbon, sulfide or $\mathrm{Fe}^{2+}$ (Postma et al., 1991; Starr and Gillham, 1993; Tesoriero et al., 2000). In many aquifers, denitrification rates are electron-donor limited due to a lack of pyrite and labile organic C. Under those conditions, $\mathrm{NO}_{3}$ is transported conservatively (Desimone and Howes, 1996; Weiskel and Howes, 1992; Wilhelm et al., 1994). Removal of $\mathrm{NH}_{4}$ mainly occurs through sorption to clays (Ceazan et al., 1989).

Reactive phosphorus in groundwater is mostly present as inorganic dissolved $\mathrm{PO}_{4}$. Under oxic conditions, dissolved $\mathrm{PO}_{4}$ is generally rapidly removed from groundwater through sorption to $\mathrm{Fe}$ oxides or co-precipitation with dissolved $\mathrm{Al}, \mathrm{Ca}$ or $\mathrm{Fe}$ in to mineral phases such as varisite $\left(\mathrm{AlPO}_{4} \cdot 2 \mathrm{H}_{2} \mathrm{O}\right)$, hydroxyapatite $\left(\mathrm{Ca}_{5}\left(\mathrm{PO}_{4}\right)_{3}(\mathrm{OH})\right.$ and strengite $\left(\mathrm{FePO}_{4} \cdot 2 \mathrm{H}_{2} \mathrm{O}\right)$ (Robertson, 1995; Weiskel and Howes, 1992; Zanini et al., 1998). Only when the removal capacity of the soil for $\mathrm{P}$ is overwhelmed by continued high fertilizer loading, $\mathrm{PO}_{4}$ will be mobile. This has been observed, for example, in oxic sandy soils in the Netherlands (Van der Molen et al., 1998) and in some septic system plumes (Robertson, 1995). Under anaerobic conditions, $\mathrm{PO}_{4}$ removal is often less efficient and occurs mainly through precipitation of mineral phases such as hydroxyapatite or vivianite $\left(\mathrm{Fe}_{3}\left(\mathrm{PO}_{4}\right)_{2} \cdot 8 \mathrm{H}_{2} \mathrm{O}\right)$.

The contrasting behaviour of $\mathrm{NO}_{3}$ and $\mathrm{PO}_{4}$ in oxic groundwater systems typically results in a strong increase of the dissolved inorganic N/P ratio along flow paths. For example, in an aquifer discharging in to Buttermilk Bay, Massachusetts, the N:P molar ratio in groundwater increases from 17 at the outlet of a septic system to 40 one meter downstream and 1000 at the downgradient edge of the watershed (Weiskel and Howes, 1992).

Nutrient removal in groundwater systems is strongly influenced by the flow rates and pathways of the groundwater on its way to inland or coastal surface waters (Carlyle and Hill, 2001; Tesoriero et al., 2000). When flow is slow, there is more time for interaction between the aqueous and the solid phase and for biological utilization. Hence, more nutrients are generally removed. Slow flow rates will also cause a time lag between changes in inputs and the discharge of nutrients to surface waters (Stalnacke et al., 2003).

\subsection{The saltwater-freshwater mixing zone}

The magnitudes and ratio of groundwater $\mathrm{N}$ and $\mathrm{P}$ inputs to coastal surface waters are significantly 
influenced by processes occurring in the mixing/transition zone (TS) of fresh groundwater (FW) and seawater (SW; Fig. 1). This mixing zone has also been termed a subterranean estuary (Moore, 1999) and is the result of dispersion during flow along the freshwater-saltwater interface. In other words, topography-driven flow of fresh water 'drags' saline water from the underlying saline groundwater body and the resulting brackish water is discharged to the sea. Convective flow of seawater replenishes the loss of salts from the dispersion zone (Cooper, 1959; Groen, 2002).

The location and width of the mixing zone is determined by the present and past freshwater input, permeability of the aquifer, sealevel, and tidal range, and can vary both on geological and shorter time scales, for example due to sealevel rise, seasonal or climate-related changes in precipitation and groundwater extraction in the coastal zone (Groen et al., 2000; Kooi and Groen, 2001; Kooi et al., 2000; Robinson et al., 1998). The mixing zone in hydrologically active systems is usually partly located below land and its width can vary from $<1 \mathrm{~m}$ to several km's (Kooi and Groen, 2001; Reilly and Goodman, 1985). Mixing of groundwater and seawater in this zone can lead to water that is either oversaturated or undersaturated with respect to calcite. Particularly in limestone aquifers (e.g. Yucatan, FL), undersaturation and the resulting calcite dissolution can greatly increase the porosity and permeability of the aquifer (Appelo and Postma, 1993; Moore et al., 2002; Sanford and Konikow, 1989).

Coastal aquifers that are subject to displacement of the mixing zone and thus to salinization or refreshening have typical, transient hydrogeochemical signatures due to cation exchange (Appelo and Postma, 1993; Beekman, 1991). Freshwater is usually dominated by $\mathrm{Ca}^{2+}$ and $\mathrm{HCO}_{3}^{-}$and cation exchangers (clay minerals, organic matter and oxides/hydroxides) in freshwater aquifers will therefore mainly be loaded with $\mathrm{Ca}^{2+}$. Upon salinization, $\mathrm{Ca}^{2+}$ on the exchanger will be replaced by $\mathrm{Na}^{+}$and $\mathrm{Mg}^{2+}$ from seawater. The mixing zone may then temporarily exhibit a $\mathrm{CaCl}_{2}$ type water. The reverse process will occur upon refreshening: $\mathrm{Ca}^{2+}$ will be taken up on the exchanger and $\mathrm{Na}^{+}$and $\mathrm{Mg}^{2+}$ will be released leading to first $\mathrm{NaHCO}_{3}$ and then $\mathrm{MgHCO}_{3}$ type water before the $\mathrm{CaHCO}_{3}$ type water breaks through. The changes in $\mathrm{Ca}^{2+}$ concentrations upon salinization and refreshening may lead to over- and undersaturation with respect to calcite and thus to calcite precipitation and dissolution, respectively.

Saltwater intrusion also leads to a significant increase in the $\mathrm{SO}_{4}$ concentration in the aquifer (seawater $\left[\mathrm{SO}_{4}\right]=29.3 \mathrm{mM}$, groundwater mostly $\left[\mathrm{SO}_{4}\right]<0.5 \mathrm{mM}$; Appelo and Postma, (1993). If the aquifer is sufficiently reduced and not $\mathrm{C}_{\text {org }}$-limited (with $\mathrm{SO}_{4}$-limited sulfate reduction or methanogenesis as the major organic matter decomposition pathways), saltwater intrusion may lead to enhanced sulfate reduction at the expense of methanogenesis. This can lead to an increase in alkalinity and the reduction of Fe-oxides with sulfide. The increased alkalinity and $\mathrm{Ca}^{2+}$ from ion exchange may enhance calcite precipitation at the salinity front (Appelo and Postma, 1993). In addition, gypsum $\left(\mathrm{CaSO}_{4} \cdot 2 \mathrm{H}_{2} \mathrm{O}\right)$ may precipitate, leading to a decrease in dissolved sulfate concentrations (Gomis-Yagues et al., 2000).

Saltwater intrusion can also increase organic carbon oxidation rates, as was recently found in the Skansehage aquifer in Denmark (Nyvang, 2003). This was attributed to salt-enhanced hydrolysis of solid organic matter upon salinization. Although the exact mechanism of organic matter destabilization is currently unknown, Nyvang (2003) postulates that the increased ionic strength weakens the divalent bonding between adsorbed organic matter and sediment particles and internally within organic matter. Degradation rates increased with time, suggesting that the microbes needed time to multiply and adapt to the seawater environment. This effect of salt-water intrusion may be independent of the redox conditions.

\subsection{Nitrogen and phosphorus dynamics and ratios in the mixing zone}

In mixing zones, which undergo only minor changes with respect to location and width, $\mathrm{N}$ and $\mathrm{P}$ transformation and removal, and thus groundwater $\mathrm{N}$ and $\mathrm{P}$ fluxes and ratios are strongly influenced by the flow rates and redox characteristics of the freshwater and seawater (Fig. 3). Flow rates are crucial in the sense that they determine the residence time in the mixing zone and thus the time spans available for removal. Oxic groundwater and seawater is defined here as water containing more than $1 \mathrm{mg} \mathrm{l}^{-1}$ dissolved 

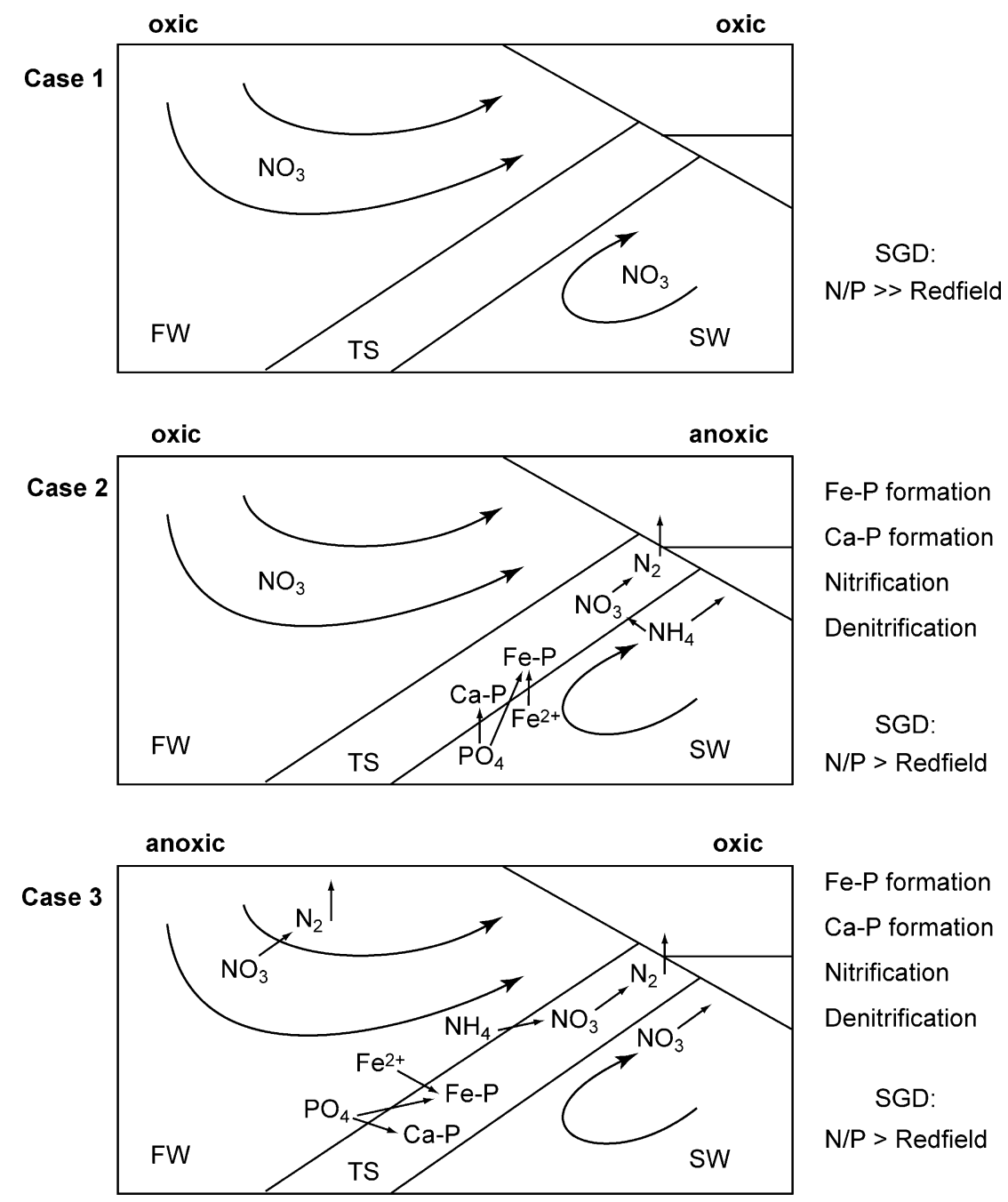

Fe-P formation

Ca-P formation

Nitrification

Denitrification

SGD:

N/P > Redfield

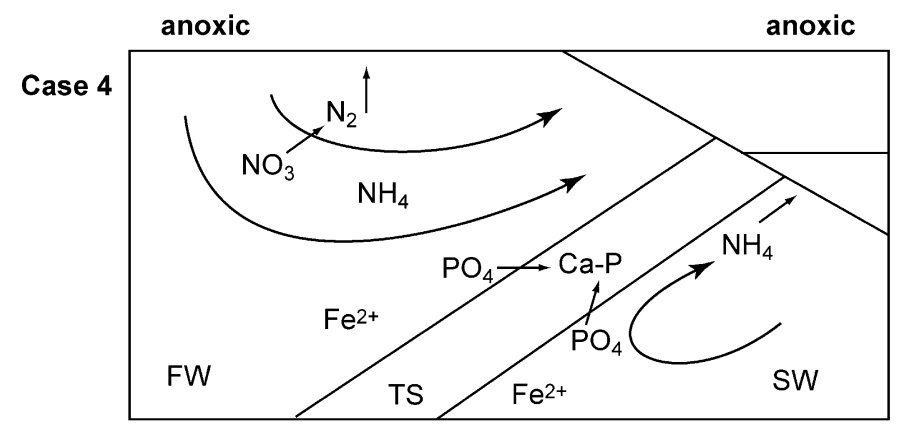

Ca-P formation

Denitrification

SGD:

N/P variable

Fig. 3. Schematic representation of the redox dependence of biogeochemical processes leading to transformation, removal or release of $\mathrm{NH}_{4}$, $\mathrm{NO}_{3}$ and $\mathrm{PO}_{4}$ when fresh groundwater (FW) meets seawater (SW) in the mixing/transition zone (TS). Case 1: oxic groundwater meets anoxic seawater; Case 2: oxic groundwater meets anoxic seawater; Case 3: anoxic groundwater meets anoxic seawater; Case 4: anoxic groundwater meets anoxic seawater. 
$\mathrm{O}_{2}$. All other waters are considered anaerobic and can range from high $\mathrm{NO}_{3}$ to $\mathrm{NH}_{4}$ plus $\mathrm{CH}_{4}$ containing waters (Fig. 2A). Anoxic coastal sediments will generally be sulfidic or methanogenic at depths of millimeters to centimeters below the seafloor. Despite their importance, redox conditions are not consistently reported in studies of SGD of nutrients. A compilation of N/P ratios in coastal groundwater from the literature (Table 1) suggests that coastal groundwater N/P ratios can vary but are mostly above the Redfield ratio of $16: 1$, particularly in contaminated systems. We will now discuss how redox conditions can affect the N/P ratio in SGD.
Where oxic groundwaters are in contact with oxic seawater (Fig. 3; Case 1), removal of $\mathrm{NO}_{3}$ through denitrification will be limited. Denitrification can only occur in anoxic micro-sites, as suggested for the mixing zone of an oxic, sandy subterranean estuary contaminated with sewage sludge in Tokyo Bay (Ueda et al., 2003). Dissolved $\mathrm{PO}_{4}$ concentrations will be negligible unless the sorption capacity of the aquifer is overwhelmed due to extremely high inputs of $\mathrm{P}$ very close to the shoreline. This may explain the extremely high dissolved $\mathrm{PO}_{4}$ concentrations in the groundwater (up to $101 \mu \mathrm{M}$ ) reported for the same Tokyo Bay site (Suzumura et al., 2000).

Table 1

Compilation of measured groundwater fluxes of $\mathrm{N}$ and $\mathrm{P}$ (in units of $\mu \mathrm{mol} \mathrm{m} \mathrm{m}^{-2} \mathrm{~d}^{-1}$ ) and groundwater $\mathrm{N} / \mathrm{P} \mathrm{ratios}(\mathrm{mol} / \mathrm{mol}$ ). $\mathrm{gw}=\mathrm{groundwater}$, sed $=$ sediment, n.a. $=$ not available. MA $=$ Massachusetts, USA

\begin{tabular}{|c|c|c|c|c|c|c|c|}
\hline $\begin{array}{l}\text { N-flux } \\
\left(\mu \mathrm{mol} \mathrm{m}{ }^{-2} \mathrm{~d}^{-1}\right)\end{array}$ & $\begin{array}{l}\text { P-flux } \\
\left(\mu \mathrm{mol} \mathrm{m}{ }^{-2} \mathrm{~d}^{-1}\right)\end{array}$ & $\begin{array}{l}\text { gw N/P } \\
(\mathrm{mol} / \mathrm{mol})\end{array}$ & Location & Geology & $\begin{array}{l}\text { Redox } \\
\text { conditions }\end{array}$ & $\begin{array}{l}\text { Main } \mathrm{N} \text { and } \\
\mathrm{P} \text { source }\end{array}$ & Reference \\
\hline $24,000-72,000$ & n.a. & $>16$ & $\begin{array}{l}\text { Nauset Marsh } \\
\text { Estuary, MA }\end{array}$ & Sandy sediment & $\begin{array}{l}\text { gw oxic, } \\
\text { sed n.a. }\end{array}$ & Sewage & Portnoy et al. (1998) \\
\hline 550 & n.a. & n.a. & Waquoit Bay, MA & $\begin{array}{l}\text { Fine to coarse } \\
\text { sand and gravel }\end{array}$ & $\begin{array}{l}\text { gw anoxic, } \\
\text { sed oxic }\end{array}$ & Sewage & Charette et al. (2001) \\
\hline 2200 & n.a. & n.a. & Town Cove, MA & $\begin{array}{l}\text { Unconsolidated } \\
\text { glacial sediment }\end{array}$ & n.a. & Sewage & Giblin and Gaines (1990) \\
\hline $430-19,000$ & n.a. & n.a. & Subestuaries, MA & $\begin{array}{l}\text { Fine to coarse } \\
\text { sand and gravel }\end{array}$ & n.a. & Sewage & $\begin{array}{l}\text { Charette et al. (2001) } \\
\text { and Valiela et al. (1992) }\end{array}$ \\
\hline n.a. & n.a. & $\begin{array}{l}270- \\
5300\end{array}$ & Buttermilk Bay, MA & $\begin{array}{l}\text { Medium to } \\
\text { coarse sand }\end{array}$ & n.a. & Sewage & Weiskel and Howes (1992) \\
\hline 301 & 0.58 & 519 & $\begin{array}{l}\text { Bay side of } \\
\text { Florida Keys }\end{array}$ & Carbonate aquifer & $\begin{array}{l}\text { gw anoxic, } \\
\text { sed anoxic }\end{array}$ & Sewage & Corbett et al. (1999) \\
\hline Up to 53,000 & up to 410 & n.a. & $\begin{array}{l}\text { Southern } \\
\text { Chesapeake Bay }\end{array}$ & Alluvium & n.a. & Fertilizer & Gallagher et al. (1996) \\
\hline n.a. & n.a. & $\sim 100$ & $\begin{array}{l}\text { Discovery Bay, } \\
\text { Jamaica }\end{array}$ & Limestone & & Human & Lapointe (1997) \\
\hline n.a. & n.a. & 36 & $\begin{array}{l}\text { Tomales Bay, } \\
\text { California }\end{array}$ & $\begin{array}{l}\text { Granite, sandstone, } \\
\text { shale, alluvium }\end{array}$ & n.a. & $\begin{array}{l}\text { Manure }+ \\
\text { sewage }\end{array}$ & Oberdorfer et al. (1990) \\
\hline 1340 & 12 & 112 & Tumon Bay, Guam & $\begin{array}{l}\text { Carbonate } \\
\text { karst aquifer }\end{array}$ & n.a. & Natural & Matson (1993) \\
\hline 920 & 37 & 25 & $\begin{array}{l}\text { Inner Kahana } \\
\text { Bay, Hawaii }\end{array}$ & Alluvium & n.a. & Natural & Garrison et al. (2003) \\
\hline 160 & 9 & 18 & $\begin{array}{l}\text { Middle Kahana } \\
\text { Bay, Hawaii }\end{array}$ & Alluvium & n.a. & Natural & Garrison et al. (2003) \\
\hline n.a. & n.a. & 5 & $\begin{array}{l}\text { Sites near } \\
\text { FSUML, Florida }\end{array}$ & $\begin{array}{l}\text { Limestone } \\
\text { and dolomite }\end{array}$ & gw anoxic & Natural & Bugna et al. (1996) \\
\hline 2400 & 900 & 3 & $\begin{array}{l}\text { North Inlet, } \\
\text { South Carolina }\end{array}$ & $\begin{array}{l}\text { Sand, gravel } \\
\text { and clay }\end{array}$ & $\begin{array}{l}\text { gw anoxic, } \\
\text { sed anoxic }\end{array}$ & Natural & Krest et al. (2000) \\
\hline n.a. & n.a. & 18 & $\begin{array}{l}\text { Crescent Beach } \\
\text { Florida }\end{array}$ & $\begin{array}{l}\text { Limestone } \\
\text { and dolomite }\end{array}$ & gw anoxic & Natural & Swarzenski et al. (2001) \\
\hline n.a. & n.a. & 18 & $\begin{array}{l}\text { Hasaki Beach, } \\
\text { Japan }\end{array}$ & Sand & $\begin{array}{l}\text { gw oxic }+ \\
\text { anoxic }\end{array}$ & n.a. & Uchiyama et al. (2000) \\
\hline
\end{tabular}


In general, SGD from oxic subterranean estuaries is expected to have very high N/P ratios due to nearly conservative transport of $\mathrm{N}$ and almost complete removal of $\mathrm{P}$.

Where oxic groundwaters come into contact with anoxic bottom sediments (Case 2), high $\mathrm{NO}_{3}$ and low $\mathrm{PO}_{4}$ groundwater meets seawater with high dissolved $\mathrm{NH}_{4}, \mathrm{PO}_{4}$ and $\mathrm{Fe}^{2+}$. This may lead to removal of seawater $\mathrm{NH}_{4}$ and groundwater $\mathrm{NO}_{3}$ in the mixing zone through nitrification and denitrification, respectively. Depending on the water chemistry, removal of $\mathrm{P}$ from the seawater may occur through formation of $\mathrm{Ca}-\mathrm{P}$ and $\mathrm{Fe}-\mathrm{P}$ minerals. The rate of denitrification in the mixing zone will depend on the flow rate of the groundwater, the availability of suitable electron donors and the degree of anoxia. Groundwater inputs of $\mathrm{NO}_{3}$ to estuarine sediments of Great South Bay, NY, have been shown to lead to increased $\mathrm{NO}_{3}$ concentrations with sediment depth (note that the reverse is found in sediments unaffected by groundwater) and denitrificaton below the sulfate reduction zone (Slater and Capone, 1989). Rates at the same site are typically organic substrate-limited at depth and $\mathrm{NO}_{3}$-limited near the sediment surface (Capone and Slater, 1990). Intermediate groundwater flow rates are required for denitrification to occur since rates that are either too high or too low will result in a dominance of advective transport over reaction or a limiting $\mathrm{NO}_{3}$ supply, respectively (Capone and Slater, 1990). Groundwater $\mathrm{NO}_{3}$ transport through high-velocity seeps, as found in shallow estuarine sediments of Nauset Marsh estuary, Cape Cod (flow rates $263 \mathrm{~m} / \mathrm{y}$ ), is nearly conservative (Giblin and Gaines, 1990; Nowicki et al., 1999; Portnoy et al., 1998). Since some groundwater $\mathrm{NO}_{3}$ but no groundwater $\mathrm{PO}_{4}$ will reach the surface waters, N/P ratios of SGD will be above Redfield.

When anoxic groundwater meets oxic seawater (Case 3), the degree of anoxia of the discharging groundwater (Fig. 2A and B) will determine the chemical characteristics of the groundwater and thus the processes affecting $\mathrm{P}$ and $\mathrm{N}$ in the coastal zone. If denitrification in the aquifer and mixing zone is Climited, high $\mathrm{NO}_{3}$ anoxic groundwater may be transported to surface waters with little modification. Groundwater $\mathrm{PO}_{4}$ and $\mathrm{NH}_{4}$ concentrations will then generally be low, since little release from organic matter will have occurred. If organic matter decomposition is not C-limited and proceeds beyond denitrification, $\mathrm{NO}_{3}$ will be absent and $\mathrm{NH}_{4}$ released from organic matter will be the major $\mathrm{N}$ form. Under these circumstances, $\mathrm{PO}_{4}$ released from organic matter and from reduction of Fe-oxides may also accumulate in the groundwater. When this $\mathrm{PO}_{4}$ and $\mathrm{Fe}^{2+}$-containing groundwater meets oxic seawater, Fe-oxide may precipitate and bind all the P. This occurs, for example, in the mixing zone of Waquoit Bay, Massachusetts (Charette and Sholkovitz, 2002). The efficiency of this process in removing $\mathrm{PO}_{4}$ will depend on the $\mathrm{Fe}^{2+} / \mathrm{PO}_{4}$ ratio in the anoxic waters (Griffioen, 1994). Part of the $\mathrm{NH}_{4}$ may be removed through nitrification and subsequent denitrification. Since no $\mathrm{PO}_{4}$ is expected to escape to the surface waters, the N/P ratios of SGD will typically be above Redfield.

When anoxic groundwater meets anoxic seawater (Case 4), the sources of $\mathrm{N}$ and $\mathrm{P}$ in groundwater will be similar to those for Case 3. The removal processes for both $\mathrm{N}$ and $\mathrm{P}$ will be more limited, however, since coupled nitrification-denitrification and $\mathrm{P}$ binding to Fe-oxides will not occur. However, $\mathrm{Ca}-\mathrm{P}$ formation may be important, particularly in carbonate aquifers. In an anoxic, saline Floridan carbonate aquifer, for example, almost complete removal of dissolved $\mathrm{P}$ through formation of a cryptocrystalline calcium phosphate was found upon injection of wastewater with $\mathrm{PO}_{4}$ concentrations $>250 \mu \mathrm{M}$ (Cable et al., 2002). Dissolved N concentrations in the mixing zone remained high. Corbett et al. (2000) showed, however, that significant removal of $\mathrm{NO}_{3}$, presumably due to denitrification, may occur upon injection of wastewater in this type of system. Depending on the sources and the efficiency of the removal processes for $\mathrm{N}$ and $\mathrm{P}$ under anoxia, the $\mathrm{N} / \mathrm{P}$ ratio of $\mathrm{SGD}$ varies and can be either larger or smaller than Redfield.

In general, when the mixing zone shows only minor variations with respect to its position, biogeochemical processes will generally remove $\mathrm{P}$ more efficiently from SGD than $\mathrm{N}$, unless the system is completely anoxic. The picture becomes different when salinization of a previously freshwater aquifer occurs. As outlined above, ion exchange processes then become important and organic matter decomposition pathways and rates may be modified. (Nyvang, 2003). In oxic aquifers 
(Cases 1 and 2), $\mathrm{PO}_{4}$ sorbed to Fe-oxides may be displaced by anions in seawater and release of $\mathrm{P}$ and $\mathrm{N}$ from organic matter may increase (Nyvang, 2003). In anoxic aquifers (Case 3 and 4), $\mathrm{NH}_{4}$ present on the exchanger will be displaced by $\mathrm{Na}^{+}$ (Beekman and Appelo, 1990; Seitzinger et al., 1991) and organic matter decomposition may be enhanced, leading to a higher release of $\mathrm{NH}_{4}$ and $\mathrm{PO}_{4}$ and sulfide-mediated reduction of Fe-oxides and release of Fe-bound $P$. Salinization of a previously freshwater aquifer thus can lead to a release of both $\mathrm{NH}_{4}$ and $\mathrm{PO}_{4}$ to the groundwater.

Depending on the loading of the aquifer solids with $\mathrm{N}$ and $\mathrm{P}$, the role of enhanced organic matter decomposition and the efficiency of $\mathrm{Ca}-\mathrm{P}$ formation, the N/P ratio of SGD can be above, equal to or below Redfield. N/P ratios above Redfield were found upon a forced salt-water intrusion in a Danish, anoxic coastal aquifer (Nyvang, 2003). Extremely low N/P ratios $(\sim 2.7)$ were reported for groundwater discharge from an anoxic, uncontaminated aquifer undergoing saltwater intrusion to salt marsh sediments in South Carolina (Krest et al., 2000). During refreshening, $\mathrm{NH}_{4}$ and $\mathrm{PO}_{4}$ are expected to replace seawater ions on the exchange complex, leading to removal of both $\mathrm{NH}_{4}$ and $\mathrm{PO}_{4}^{-}$from the groundwater. $\mathrm{NO}_{3}^{-}$will pass unchanged and N/P ratios are expected to be above Redfield.

The efficiency of the removal of $\mathrm{N}$ and $\mathrm{P}$ in the subterranean estuary may vary seasonally. Denitrification rates are very sensitive to temperature changes (Holtan-Hartwig et al., 2002) and are expected to be lowest in winter. $\mathrm{P}$ removal may be more efficient, however, due to the generally more oxic sediment conditions. As a consequence $\mathrm{N} / \mathrm{P}$ ratios in SGD are expected to be higher in winter than in summer. This was observed to be the case for N/P ratios of SGD and the receiving surface waters of Buzzards Bay in Massachusetts (Valiela et al., 1990).

Summarizing, groundwater $\mathrm{N}$ (mostly as $\mathrm{NO}_{3}$ ) is generally less efficiently removed than $\mathrm{P}$. This explains why $\mathrm{N} / \mathrm{P}$ ratios greater than Redfield are most common in SGD (Table 1). N/P ratios of SGD significantly below Redfield can be found upon discharge from anoxic aquifers and may point to salinization of the aquifer.

\section{Rates of submarine groundwater discharge of $\mathbf{N}$ and $P$ and the effects on a local and regional scale}

SGD associated fluxes of $\mathrm{N}$ and $\mathrm{P}$ are typically estimated as the product of measured or calculated ground water fluxes and ground water or sediment porewater concentrations of $\mathrm{N}$ and $\mathrm{P}$. When using groundwater concentrations it is assumed that transport through the salt water-fresh water mixing zone is conservative. Direct measurements of nutrient concentrations and seepage rates with incubation chambers are rare (e.g., Portnoy et al., 1998). Analogous to groundwater fluxes (Taniguchi et al., 2002), SGD associated $N$ and $P$ fluxes are often reported in units of (1) mass per length of shoreline per unit time, (2) mass per $\mathrm{m}^{2}$ per unit time, or (3) mass per unit time. Interconversion of units is possible only when the area of the region where SGD occurs is known. A compilation of groundwater flux estimates for $\mathrm{N}$ and $\mathrm{P}$ from the literature in units of $\mu \mathrm{mol} \mathrm{m} \mathrm{m}^{-2} \mathrm{~d}^{-1}$ (Table 1) shows that rates can vary over orders of magnitude. The lower values for $\mathrm{N}$ and most values for $\mathrm{P}$ are within the same range as typical recycling rates of $\mathrm{N}$ and $\mathrm{P}$ in coastal sediments $(\mathrm{N}$ : mostly $0-1000 \mu \mathrm{mol} \mathrm{m} \mathrm{m}^{-2} \mathrm{~d}^{-1}$; $\mathrm{P}$ : on average: ca. $1230 \mu \mathrm{mol} \mathrm{m}{ }^{-2} \mathrm{~d}^{-1}$ for the shelf and slope) (Meile and Van Cappellen, 2003; Middelburg et al., 1996). In some cases, SGD estimates may actually include the flux of recycled nutrients. The highest SGD rates of $\mathrm{N}$ are observed in aquifers contaminated with sewage. The highest rate of SGD of $\mathrm{P}$ is found in the anoxic $\mathrm{S}$. Carolina aquifer that is subject to salinization (Krest et al., 2000).

Quantitative studies on groundwater nutrient inputs to the coastal zone have been carried out in a small number of regions only, and many of these are located in the United States (Tables 1 and 2). These studies suggest that groundwater inputs of nutrients may rival river inputs on a regional scale (Table 2) and may play an important role in determining the nutrient availability, species diversity and primary production in the coastal zone (Gobler and Sanudo-Wilhelmy, 2001; Moore and Shaw, 1998; Rutkowski et al., 1999; Sewell, 1982; Valiela et al., 1990). In particular, the input of contaminated groundwater with a high N/P ratio (Table 1) may significantly impact the ecology of coastal waters by driving N-limited 
Table 2

Comparison of estimated $\mathrm{N}$ and $\mathrm{P}$ fluxes through SGD to river fluxes

\begin{tabular}{llll}
\hline Location & SGD N: river N & SGD P: river P & Reference \\
\hline $\begin{array}{lll}\text { Coastal bays, New England } \\
\text { Perth Region, West Australia }\end{array}$ & $2: 1$ to $32: 1$ & n.a. & Valiela et al. (1990) \\
& $3: 1$ to $5: 1$ & n.i. & and Hearn (1985) \\
Kahana Bay, Hawaii & & & Garrison et al. (2003) \\
Florida Bay & $2: 1$ & $5: 1$ & Corbett et al. 1999 \\
Turkey Pt, St. Joseph Bay, Florida & $\sim 1: \sim 1$ & $\sim 1: \sim 1$ & Rutkowski et al. (1999) \\
S. Carolina, salt marsh input & $1: 1$ & $1: 1$ & Krest et al. (2000) \\
S. Carolina, incl. offshore input & $1: 1$ & $1.2: 1$ & (Moore, 2002 \\
Tomales Bay, CA, summer & $3.6: 1$ & $1.2: 1$ & Oberdorfer et al. (1990) \\
Tomales Bay, CA, winter & $7: 1$ & $3.7: 1$ & Oberdorfer et al. (1990) \\
Kashima Sea, Japan & $1: 3.4$ & $1: 2.7$ & (Uchiyama et al., 2000 \\
\hline
\end{tabular}

n.i., not important; n.a., not available.

systems to P-limitation (Lapointe, 1997; Valiela et al., 1990) and thus stimulating harmful algal blooms (Kim et al., 2004).

\section{Effect of SGD inputs of nutrients on a global scale: a model approach}

The limited number of local and regional studies precludes an accurate assessment of the importance of SGD of nutrients on a global scale. Clearly, more experimental and modeling studies are needed in key regions. Particularly, areas in developing countries with increasing population densities and fertilizer use (e.g. Asia and South America) are of interest, since, analogous to rivers (Rabouille et al., 2001; Seitzinger and Kroeze, 1998; Seitzinger et al., 2002; Smith et al., 2003), these are the regions where inputs of nutrients to groundwater are expected to increase most.
Here, we will assess the potential effects of groundwater inputs of nutrients using a dynamic box model for the biogeochemical cycles of $\mathrm{C}, \mathrm{N}$ and $\mathrm{P}$ in the proximal zone. This zone includes large bays, the open water part of estuaries, deltas, inland seas and salt marshes (for dimensions, see Table 3) (Rabouille et al., 2001), that is, the part of the land-ocean transition that is most influenced by changes in river and groundwater inputs.

\subsection{Model description}

Our model is based mainly on the coastal ocean C, N, O model of Rabouille et al. (2001) and the global C and P model of Van Cappellen and Ingall (1994). More details on the modeling methodology are described elsewhere (Mackenzie et al., 1993; Ver et al., 1999a). A graphical representation of the model is shown in Fig. 4. N and P input are assumed to occur

Table 3

Reservoirs of the coupled, pre-anthropogenic P, C and N cycles in the proximal zone of the coastal ocean. Dimensions of the proximal zone: surface area $=1.8 \times 10^{12} \mathrm{~m}^{2}$, mean depth $=20 \mathrm{~m}$, volume $36 \times 10^{12} \mathrm{~m}^{3}$, water residence time $=0.97 \mathrm{y}($ Rabouille et al., 2001)

\begin{tabular}{lllll}
\hline Reservoir & Description & Size (mol) & $\begin{array}{l}\text { Residence } \\
\text { time (y) }\end{array}$ \\
\hline 1. SRN & Water column inorganic N & $0.18 \times 10^{12}$ & 0.02 & Reference \\
2. PON & Water column organic N & $3 \times 10^{12}$ & 0.50 & Rabouille et al. (2001) \\
3. SRP & Water column inorganic P & $1.8 \times 10^{10}$ & 0.04 & Assuming SRP $=0.5 \mu M$; \\
& & & 0.47 & N/P $=10$ \\
4. POP & Water column organic P & $1.88 \times 10^{11}$ & PON/16 \\
5. POC & Water column organic C & $19.9 \times 10^{12}$ & 0.50 & PON $\times 6.6($ Redfield $)$ \\
\hline
\end{tabular}



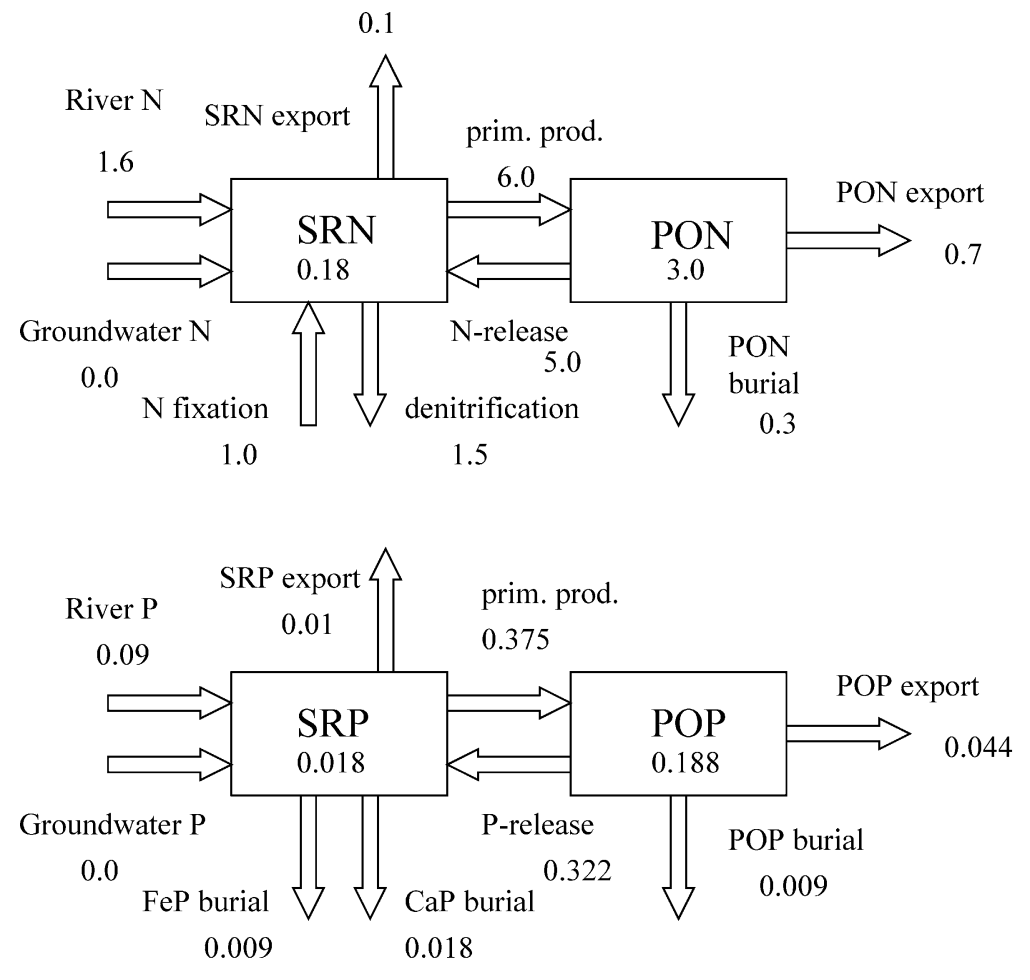

prim. prod.

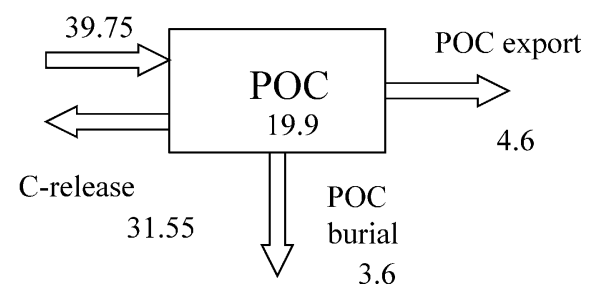

Reservoirs in Tmol

Fluxes in Tmol $\mathrm{y}^{-1}$

Fig. 4. Pre-human steady-state biogeochemical cycles of $\mathrm{C}, \mathrm{P}$ and $\mathrm{N}$ in the proximal coastal zone. Reservoirs in Tmol. Fluxes in Tmol yr ${ }^{-1}$.

as riverine soluble reactive $\mathrm{N}$ and $\mathrm{P}$ (SRN and SRP, respectively, defined as the sum of the dissolved reactive $\mathrm{N}$ and $\mathrm{P}$ and the particulate reactive $\mathrm{N}$ and $\mathrm{P}$ that becomes soluble in the coastal zone), groundwater soluble reactive $\mathrm{N}$ and $\mathrm{P}$, and for $\mathrm{N}$, through fixation from the atmosphere. Following Rabouille et al. (2001), atmospheric deposition of $\mathrm{N}$ to the proximal zone is assumed zero. Uptake by phytoplankton results in production of organic $\mathrm{N}(\mathrm{PON})$ and $\mathrm{P}$ (POP). Burial of Fe-bound and organic $\mathrm{P}$, and denitrification rates are very dependent on redox conditions. Previous work (Rabouille et al., 2001) has shown that the oxygen concentration in the water column will show little change upon typical increases in mineralization rates due to anthropogenic impact. This is why we did not include the $\mathrm{O}$ cycle and the redox dependence of the removal processes for $\mathrm{N}$ and $\mathrm{P}$ in this model. For $\mathrm{C}$, we only model the organic $\mathrm{C}$ (POC) in the phytoplankton biomass. This organic $\mathrm{C}$ is formed through primary production and removed through organic matter decomposition, burial and export to the distal coastal zone.

The reservoir sizes and steady state fluxes for preanthropogenic conditions adopted in our model are presented in Fig. 4 and Tables 3 and 4. We used the flux values of the $\mathrm{N}$ model of Rabouille et al. (2001) 
Table 4

Steady state fluxes of $\mathrm{P}, \mathrm{C}$ and $\mathrm{N}$ in the proximal zone of the coastal ocean and calculated first order rate constants $(k)$ as used in the model

\begin{tabular}{|c|c|c|c|c|}
\hline Flux & Description & $\begin{array}{l}\text { Flux, } \\
\left(\text { Tmol yr }^{-1}\right)\end{array}$ & $\begin{array}{l}\mathrm{k} \\
\left(\mathrm{yr}^{-1}\right)\end{array}$ & References and comments \\
\hline NF1 & River SRN flux & 1.6 & - & Rabouille et al. (2001) \\
\hline NF2 & Groundwater SRN flux & 0.0 & - & \\
\hline NF3 & SRN export & 0.1 & & Rabouille et al. (2001) \\
\hline NF4 & Primary production & 6.0 & See CF1 & Rabouille et al. (2001) \\
\hline NF5 & SRN release from PON & 5.0 & 1.66 & Rabouille et al. (2001) \\
\hline NF6 & Denitrification & 1.5 & $3.93 \times 10^{-6}(\operatorname{sqrt}(\operatorname{mol~y}))^{-1}$ & Rabouille et al. (2001) \\
\hline NF7 & N-fixation & 1.0 & - & Rabouille et al. (2001) \\
\hline NF8 & PON burial & 0.3 & 0.1 & Rabouille et al. (2001) \\
\hline NF9 & PON export & 0.7 & 0.23 & Rabouille et al. (2001) \\
\hline $\mathrm{PF} 1$ & River SRP flux & 0.09 & - & $\begin{array}{l}\text { Berner and Rao (1994) } \\
\text { and Howarth et al. (1995) }\end{array}$ \\
\hline PF2 & Groundwater SRP flux & 0.0 & - & \\
\hline PF3 & $\mathrm{Fe}-\mathrm{P}$ burial & 0.009 & 0.5 & $\begin{array}{l}\text { Total } \mathrm{P} \text { burial }=\mathrm{PF} 1+ \\
\mathrm{PF} 2-\mathrm{PF} 5-\mathrm{PF} 9,50 \% \text { as } \\
\mathrm{CFA}, 25 \% \text { as org. P, } 25 \% \\
\text { as Fe-P (Ruttenberg, } 1993\end{array}$ \\
\hline PF4 & $\mathrm{Ca}-\mathrm{P}$ burial & 0.018 & 0.056 (dim. less) & See PF3 \\
\hline PF5 & SRP export & 0.01 & 0.555 & $\mathrm{NF} 3 \times \mathrm{SRP} / \mathrm{SRN}$ ratio \\
\hline PF6 & Primary production & 0.375 & See CF1 & NF5/16 \\
\hline PF7 & Release of SRP from POP & 0.322 & 1.71 & PF6-PF8-PF9 \\
\hline PF8 & POP burial & 0.009 & 0.048 & See PF3 \\
\hline PF9 & POP export & 0.044 & 0.23 & NF8/16 \\
\hline $\mathrm{CF} 1$ & Primary production & 39.75 & $k_{\text {photo }}=2.8$, see text & $\mathrm{NF} 4 \times 6.6$ \\
\hline $\mathrm{CF} 2$ & Release of C from POC & 31.55 & 1.58 & CF1-CF3-CF4 \\
\hline $\mathrm{CF} 3$ & POC burial & 3.6 & 0.18 & $\mathrm{NF} 8 \times 12$ \\
\hline $\mathrm{CF} 4$ & POC export & 4.6 & 0.23 & $\mathrm{NF9} \times 6.6$ \\
\hline
\end{tabular}

sqrt, square root.

and calculated the corresponding $\mathrm{C}$ and $\mathrm{P}$ fluxes assuming a Redfield ratio of 106:16:1 for phytoplankton and a $\mathrm{C}: \mathrm{N}$ ratio of 12 for organic matter buried in the coastal sediment (Rabouille et al., 2001). A riverine reactive $\mathrm{P}$ input of $9.0 \times 10^{10} \mathrm{~mol} \mathrm{yr}^{-1}$ is assumed (Berner and Rao, 1994; Howarth et al., 1995). Carbonate fluorapatite (CFA), organic $P$ and Fe-bound $\mathrm{P}$ account for 50, 25 and 25\%, respectively, of the total sediment $\mathrm{P}$ burial flux in coastal sediments (Ruttenberg, 1993). Remaining steady state fluxes were calculated from mass balance requirements.

Process rate descriptions were in most cases obtained from the initial steady state fluxes, by assuming first-order rate laws, with the flux calculated as the product of a rate constant $k$ (Table 4 ) and the initial steady state mass of the source reservoir. There are several exceptions, however. $\mathrm{N}$-fixation from the atmosphere is assumed to be a constant flux
(Rabouille et al., 2001). This is a reasonable assumption because $\mathrm{N}$-fixation in coastal ecosystems is rarely able to make up a deficit in $\mathrm{N}$ availability (Howarth, 1988). Primary productivity (PP in mol

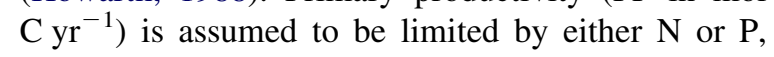
following Liebig's law of the minimum:

$$
\begin{aligned}
\mathrm{PP}= & k_{\text {photo }} \times \mathrm{POC} \\
& \times \text { minimum }\left(\frac{[\mathrm{SRN}]}{[\mathrm{SRN}]+K_{\mathrm{N}}}, \frac{[\mathrm{SRP}]}{[\mathrm{SRP}]+K_{\mathrm{P}}}\right)
\end{aligned}
$$

where $k_{\text {photo }}$ is the maximum rate constant for primary production $\left(\mathrm{yr}^{-1}\right)$, POC is the amount of organic carbon biomass in the water column (mol), SRN is the soluble reactive $\mathrm{N}$ concentration $(\mu \mathrm{M})$, SRP is the soluble reactive $P$ concentration $(\mu M)$, and $K_{N}$ and $K_{P}$ are the half saturation concentrations $(\mu \mathrm{M})$ for growth with $\mathrm{N}$ or $\mathrm{P}$ as limiting nutrient, respectively 

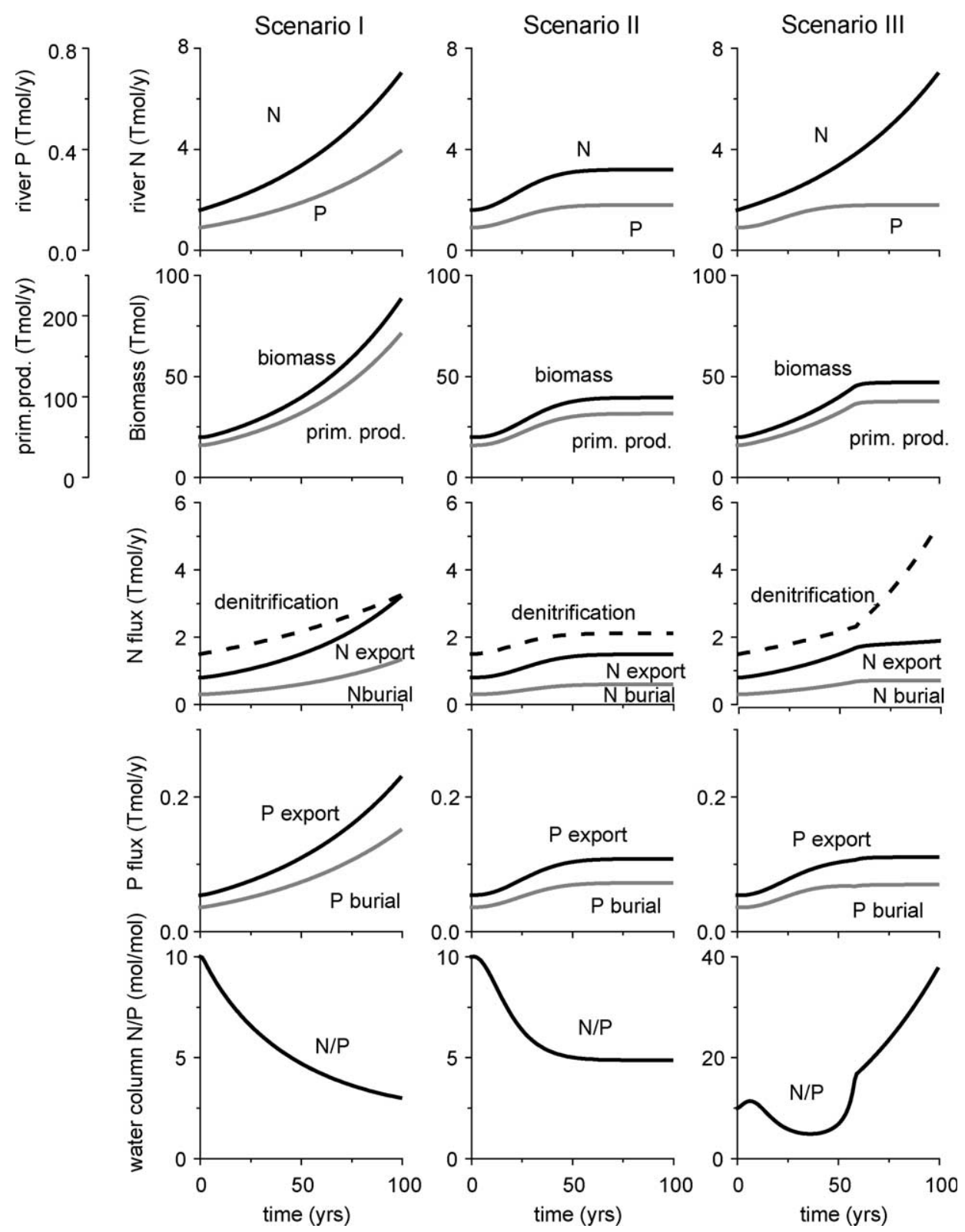

Fig. 5. Response of selected C, N, P processes (primary productivity, denitrification, burial and export of inorganic + organic $\mathrm{N}$ and $\mathrm{P}$; $\mathrm{Tmol} \mathrm{yr}^{-1}$ ), the amount of biomass (Tmol) and water column N/P ratios ( $\mathrm{mol} \mathrm{mol}^{-1}$ ) in the proximal coastal zone to increased riverine input of $\mathrm{N}$ and P. Scenario I: exponential increase of riverine N and P; Scenario II: semi-gaussian increase of riverine N and P; Scenario III: exponential increase of riverine $\mathrm{N}$, semi-gaussian increase of riverine $\mathrm{P}$. A primary productivity of $100 \mathrm{Tmol} / \mathrm{y}$ is equivalent to $667 \mathrm{~g} \mathrm{C}^{2} \mathrm{yr}^{-1}$. For further details, see text.

$\left(K_{\mathrm{N}}=2.0 \mu \mathrm{M}, \quad\right.$ (Rabouille et al., 2001) $K_{\mathrm{P}}=0.124 \mu \mathrm{M}$, based on range of $0.03-0.3 \mu \mathrm{M}$ (Tyrrell, 1999; Veldhuis et al., 1991)). The rate of $\mathrm{Ca}-\mathrm{P}$ (carbonate fluorapatite) formation is expected to depend on the rate of regeneration of $\mathrm{P}$ from organic matter (Van Cappellen and Ingall, 1994) and here is described as the product of the release rate of $\mathrm{P}$ from $\mathrm{POP}$ and a proportionality constant. 
Denitrification rates are most sensitive to nitrate and oxygen concentrations in the water column and the flux of labile organic matter reaching the sediment (Middelburg et al., 1996). At higher rates of organic matter deposition, the denitrification efficiency may decrease because of increased sediment anoxia and decreased nitrification (Rabouille et al., 2001). To account for these factors, denitrification rates are assumed to depend on the nitrate concentration in the water column, the square root of release of $\mathrm{N}$ from PON and a kinetic constant. The choice of model parameters makes the proximal zone in its pre-anthropogenic state $\mathrm{N}$-limited. The input fluxes of riverine and groundwater $\mathrm{N}$ and $\mathrm{P}$ are used as forcing functions to assess the effects of anthropogenic impact on nutrient inputs to and nutrient limitation in the coastal zone.

\subsection{Human perturbation of river inputs of nutrients}

Most of the increase in inputs of $\mathrm{N}$ and $\mathrm{P}$ to the coastal zone due to anthropogenic activity has occurred since 1950 (Mackenzie et al., 2002; Rabouille et al., 2001; Ver et al., 1999b). This is assumed to have led to approximately a doubling of the river fluxes of reactive $\mathrm{N}$ and $\mathrm{P}$ between 1950 and 2000 (Mackenzie et al., 2002; Meybeck, 1982; Rabouille et al., 2001). In our simulations, we assess the period between 1950 and 2050 (time $=0-100 \mathrm{yr}$ ), let the riverine inputs increase by ca. a factor 2 within the first $50 \mathrm{yr}$ and consider three scenarios: (I) a business-as-usual scenario, with $\mathrm{N}$ and $\mathrm{P}$ inputs continuing to grow exponentially after the year 2000 (II) a strong increase of river inputs of both $\mathrm{N}$ and $\mathrm{P}$ after 1950, followed by a stabilization around the year 2000, and (III) an exponential increase of $\mathrm{N}$ inputs but stabilization of river inputs of $\mathrm{P}$ around the year 2000 after an initial rapid increase (Fig. 5). Scenarios I and II are similar to simulations carried out by Rabouille et al. (2001) for N. A semigaussian function with a sigma of $30 \mathrm{yr}$ is used for the increase and stabilization of riverine nutrient input in scenario's (II) and (III):

$S R N(t)=S R N_{\text {final }}+\left(S R N_{\text {initial }}-S R N_{\text {final }}\right) e^{-\left(t^{2} / 30^{2}\right)}$

The equation used to describe the exponential increase of riverine inputs of $\mathrm{N}$ (and $\mathrm{P}$ ) is:

$\operatorname{SRN}(t)=\operatorname{SRN}_{\text {initial }}(1.015)^{t}$
Only in scenario (II), will the system reach a new steady state after the perturbation. In the first set of base-line simulations shown in Fig. 5, groundwater inputs of $\mathrm{N}$ and $\mathrm{P}$ are assumed to be zero.

As in the model calculations of Rabouille et al. (2001), a doubling of river inputs of both $\mathrm{N}$ and $\mathrm{P}$ leads to approximately a factor 2 increase in biomass and primary production in the proximal coastal ocean. Rates of removal of $\mathrm{N}$ and $\mathrm{P}$ through burial, export and denitrification also increase. Most of the export of $\mathrm{N}$ and $\mathrm{P}$ is in the form of organic matter. In scenario I, II and the first part of scenario III, water column N/P ratios gradually decline. This means that the proximal coastal ocean is becoming more N-limiting upon increased nutrient loading (riverine input N/P ratio $=18$ ). This is because of more efficient recycling of $\mathrm{P}$ than $\mathrm{N}$ in the coastal ocean and is in accordance with the low N/P ratios observed in many estuarine waters in the United States (Howarth, 1988).

In the second part of scenario III, where riverine $\mathrm{P}$ loads are assumed to stabilize gradually and $\mathrm{N}$ loads continue to increase, water column N/P ratios exceed 16 approximately $60 \mathrm{yr}$ into the simulation and a shift to P-limitation takes place. The amount of $\mathrm{P}$ in the system stabilizes, and so do rates of primary productivity and the biomass in the water column. Denitrification rates continue to increase because of a continued riverine input of $\mathrm{N}$ and increase in dissolved $\mathrm{N}$ concentrations in the water column.

\subsection{Groundwater input of nutrients}

Groundwater input can affect nutrient cycling in the proximal coastal zone by (1) supplying the limiting nutrient and increasing primary production and, (2) changing the limiting nutrient from $\mathrm{N}$ to $\mathrm{P}$ With the model, we assessed how much groundwater input with a N/P ratio of 100 is needed to drive the systems of scenario I and II to P-limitation within the time span of our simulation, i.e. $100 \mathrm{yr}$. We did not consider scenario III, since in this scenario the system already becomes $\mathrm{P}$ limited and groundwater input will have little additional effect. In both cases, we assumed that groundwater inputs follow the time pattern assumed for riverine inputs, but with a delay to account for the time needed for travel of the groundwater through shallow coastal aquifers. For scenario I, there is no groundwater input during 

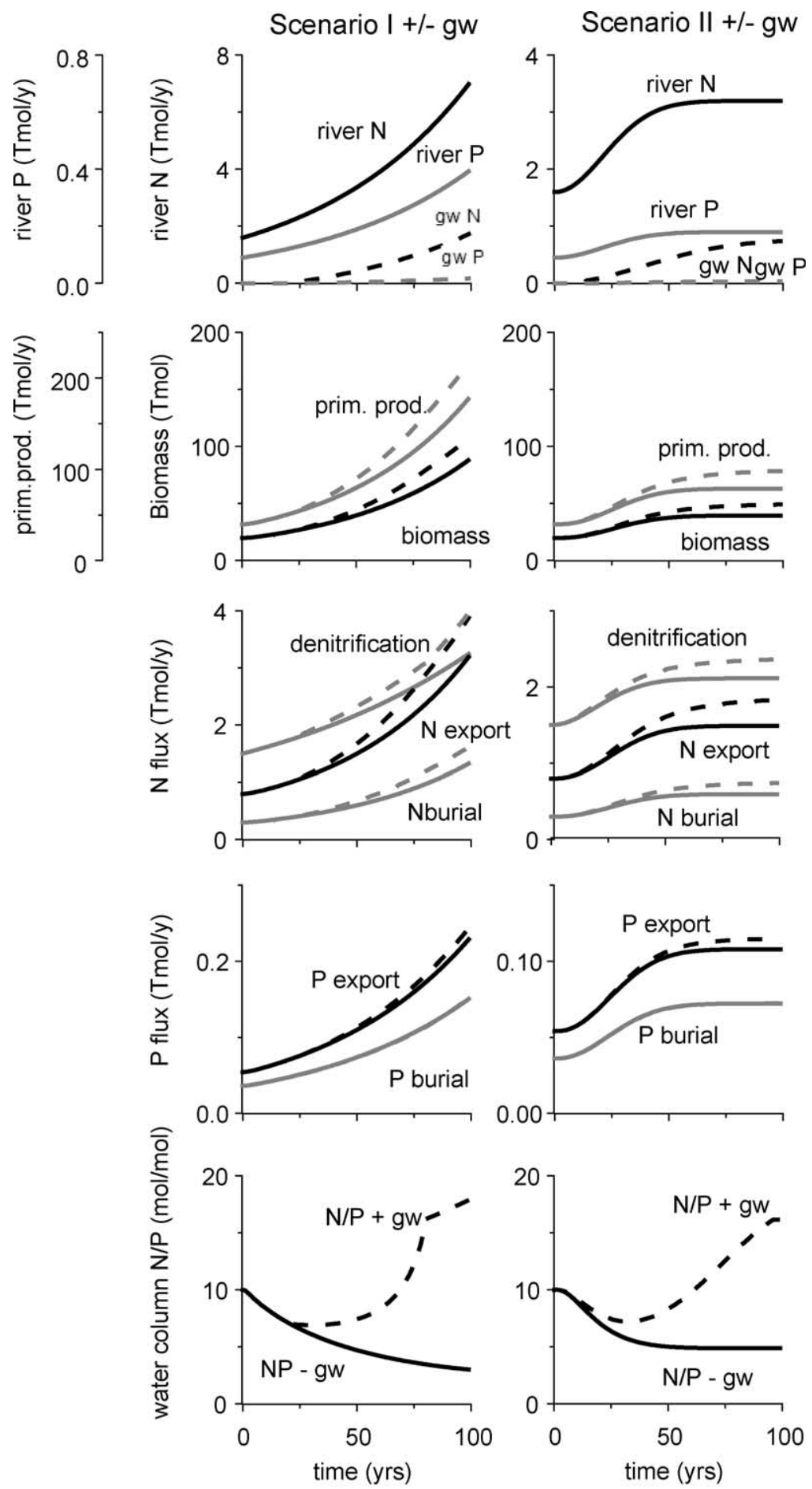

Fig. 6. Response of the selected C, N, P processes (primary productivity, denitrification, $\mathrm{N}$ and $\mathrm{P}$ burial and export; Tmol $\mathrm{yr}^{-1}$ ), the amount of biomass (Tmol) and water column N/P ratios $\left(\mathrm{mol} \mathrm{mol}^{-1}\right)$ in the proximal coastal zone to increased riverine (solid lines) and groundwater inputs (dashed lines) of $\mathrm{N}$ and P. For Scenarios, see Fig. 5 and text. 
the first $20 \mathrm{yr}$, then there is an increase following:

$\operatorname{SRN}(t)=-A+A(1.015)^{(t-30)}$

where $A$ is a constant ( $\mathrm{Tmol} \mathrm{N} \mathrm{yr}^{-1}$ ). For scenario II, we assume a sigma of $55 \mathrm{yr}$ for the semigaussian increase described in Eq. (2). For scenario I, an increase in groundwater $\mathrm{N}$ input to $1.14 \mathrm{Tmol} \mathrm{N} \mathrm{yr}^{-1}$ is needed to drive the system to $\mathrm{P}$ limitation (Fig. 6A;

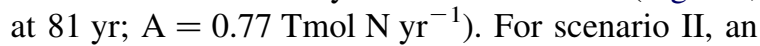
increase to $0.73 \mathrm{Tmol} \mathrm{N} \mathrm{yr}^{-1}$ is required (Fig. 6B; at $96 \mathrm{yr} ; \mathrm{SRN}_{\mathrm{ini}}=0.0, \mathrm{SRN}_{\mathrm{final}}=0.77 \mathrm{Tmol} \mathrm{N} \mathrm{yr}^{-1}$ ). In both cases, the increased nutrient input to the coastal zone leads to an increase in biomass and primary production (both by a factor of $\sim 1.2$ ) and $\mathrm{N}$ and $\mathrm{P}$ removal (Fig. 6). Whether these groundwater inputs could be realistic can be assessed by calculating the required groundwater $\mathrm{N}$ concentrations at the time of the switch, assuming that ca. 5\% of the total global water flux $\left(37 \mathrm{Tm}^{3}\right.$; (Berner and Berner, 1996) is through SGD (see Section 2.1)). For scenario I and II, the estimated concentrations are 616 and $395 \mu \mathrm{M} \mathrm{N}$, respectively, and thus are within the range for septicsystem sewage plumes and groundwater below fertilized land (see Section 2.3). Assuming that active groundwater discharge takes place in ca. $1 \%$ of the proximal zone (total area of $18 \times 10^{12} \mathrm{~m}^{2}$; (Rabouille et al., 2001)), the corresponding $\mathrm{N}$-flux in $\mu \mathrm{M} \mathrm{m}^{2} \mathrm{~d}^{-1}$ will be ca. 17,350 and 11,100, for Scenario I and II, respectively. These values are within the highest part of the range of $\mathrm{N}$ fluxes measured for contaminated groundwater in the coastal zone (Table 1). These results indicate that substantial contamination of coastal groundwater with $\mathrm{N}$ is needed in the key areas where most SGD occurs to initiate a global scale switch from N-limitation to P-limitation and to significantly enhance primary productivity and biomass in the proximal coastal zone.

\section{Conclusions}

SGD is probably quantitatively most important in shallow, permeable (sand, limestone) coastal aquifers with high rates of groundwater recharge. The major sources of $\mathrm{N}$ and $\mathrm{P}$ to coastal groundwater are natural inputs from organic matter decomposition and, for $\mathrm{P}$, mineral dissolution, and anthropogenic inputs from fertilizer, manure and wastewater. The residence time in the groundwater system and the redox conditions strongly determine the transformation, removal and transport of groundwater N and P. Removal processes for $\mathrm{P}$ in groundwater are generally more efficient than those for $\mathrm{N}$. As a consequence, N/P ratios of SGD above the Redfield ratio (16:1) are most common. Only in some anoxic aquifers and upon salinization are lower N/P ratios observed. Flux estimates of $\mathrm{N}$ and $P$ through SGD vary over orders of magnitude. Highest rates for $\mathrm{N}$ are observed in aquifers contaminated with sewage. Quantitative studies for areas in the US and Australia suggest that groundwater inputs of $\mathrm{N}$ and $\mathrm{P}$ may rival river inputs on a regional scale.

We assessed the possible role of groundwater inputs of nutrients on a global scale using a new model for the cycles of $\mathrm{C}, \mathrm{N}$ and $\mathrm{P}$ in the global proximal coastal zone (modified from the $\mathrm{C}, \mathrm{N}, \mathrm{O}$ model of Rabouille et al., 2001). This is the nearshore part of the coastal zone that directly receives the input from rivers and groundwater and includes large bays, the open water part of estuaries, deltas, inland seas and salt marshes. We showed that a doubling of river input of $\mathrm{N}$ and $\mathrm{P}$ leads to a factor 2 increase in primary production and biomass and a decline in water column $\mathrm{N} / \mathrm{P}$ ratios, i.e. the system becomes more $\mathrm{N}$-limiting. With the model, we assessed how much groundwater input with a N/P ratio of 100 is needed to drive the system to P-limitation, within the time-span of our simulation $(100 \mathrm{yr})$. The results indicate that a very strong contamination of coastal groundwater with $\mathrm{N}$ is required in the areas where SGD occurs for a substantial impact of SGD on coastal marine productivity.

Future research on groundwater discharge to the coastal zone should include detailed experimental and modeling studies of the biogeochemical processes in the saltwater-freshwater mixing zone of coastal aquifers and in near-coastal sediments. Particularly insight in the redox conditions in coastal aquifers is essential since these strongly determine the transformation and mobility of nutrients in groundwater. Future study areas should include tectonically active coastal areas (e.g. Western coastline of the United States) and developing countries (e.g. SE Asia). 


\section{Acknowledgements}

This research was made possible by a fellowship of the Royal Netherlands Academy of Arts and Sciences (KNAW) to C.P. Slomp. We thank C. Meile and C. Spiteri for comments on the draft manuscript.

\section{References}

Appelo, C.A.J., Postma, D., 1993. Geochemistry, Groundwater and Pollution, Balkema, Amsterdam.

Beekman, H.E., 1991. Ion chromatography of fresh and seawater intrusion, Free University, Amsterdam.

Beekman, H.E., Appelo, C.A.J., 1990. Ion chromatography of freshand salt-water displacement: laboratory experiments and multicomponent transport modeling. Journal of Contaminant Hydrology $7,21-37$.

Berner, E.K., Berner, R.A., 1996. Global Environment: Water Air and Geochemical cycles, Prentice Hall, New Jersey, pp. 376.

Berner, R.A., Rao, J.L., 1994. Phosphorus in sediments of the Amazon river and estuary: implications for the global flux of phosphorus to the sea. Geochimica et Cosmochimica Acta 58, 2333-2339.

Bokuniewicz, H., 1980. Groundwater seepage into Great South Bay, New York. Estuarine Coastal and Shelf Science 10, 437-444.

Bokuniewicz, H., Pavlik, B., 1990. Groundwater seepage along a barrier-Island. Biogeochemistry 10(3), 257-276.

Brun, A., Engesgaard, P., Christensen, T.H., Rosbjerg, D., 2002. Modelling of transport and biogeochemical processes in pollution plumes: Vejen landfill, Denmark. Journal of Hydrology 256(3-4), 228-247.

Bugna, G.C., Chanton, J.P., Cable, J.E., Burnett, W.C., Cable, P.H., 1996. The importance of groundwater discharge to the methane budgets of nearshore and continental shelf waters of the northeastern Gulf of Mexico. Geochimica et Cosmochimica Acta 60(23), 4735-4746.

Burnett, W.C., Bokuniewicz, H., Huettel, M., Moore, W.S., Taniguchi, M., 2003. Groundwater and pore water inputs to the coastal zone. Biogeochemistry 66, 3-33.

Burnett, W.C., Taniguchi, M., Oberdorfer, J., 2001. Measurement and significance of the direct discharge of groundwater into the coastal zone. Journal of Sea Research 46(2), 109-116.

Cable, J.E., Bugna, G.C., Burnett, W.C., Chanton, J.P., 1996a. Application of $\mathrm{Rn}-222$ and $\mathrm{CH} 4$ for assessment of groundwater discharge to the coastal ocean. Limnology and Oceanography 41(6), 1347-1353.

Cable, J.E., Burnett, W.C., Chanton, J.P., Weatherly, G.L., 1996 b. Estimating groundwater discharge into the northeastern Gulf of Mexico using radon-222. Earth and Planetary Science Letters 144(3-4), 591-604.

Cable, J.E., Burnett, W.C., Chanton, J.P., 1997a. Magnitude and variations of groundwater seepage along a Florida marine shoreline. Biogeochemistry 38(2), 189-205.
Cable, J.E., Burnett, W.C., Chanton, J.P., Corbett, D.R., Cable, P.H., 1997b. Field evaluation of seepage meters in the coastal marine environment. Estuarine Coastal and Shelf Science 45(3), $367-375$.

Cable, J.E., Corbett, D.R., Walsh, M.M., 2002. Phosphate uptake in coastal limestone aquifers: a fresh look at wastewater management. Limnology and Oceanography Bulletin 11(2), $1-4$.

Capone, D.G., Slater, J.M., 1990. Interannual patterns of water-table height and groundwater derived nitrate in nearshore sediments. Biogeochemistry 10(3), 277-288.

Caraco, N.F., 1995. Influence of human populations on $\mathrm{P}$ transfers to aquatic systems: a regional scale study using large rivers. Phosphorus in the global environment. In: Tiessen, H., (Ed.), Transfers, Cycles and Management. SCOPE, Wiley, New York, pp. 235-244.

Carlyle, G.C., Hill, A.R., 2001. Groundwater phosphate dynamics in a river riparian zone: effects of hydrologic flowpaths, lithology and redox chemistry. Journal of Hydrology 247, $151-168$.

Ceazan, M.L., Thurman, E.M., Smith, R.L., 1989. Retardation of ammonium and potassium transport through a contaminated sand and gravel aquifer: the role of cation exchange. Environmental Science and Technology 23, 1402-1408.

Chapelle, F.H., 2001. Groundwater Microbiology and Geochemistry, Wiley, New York.

Chapelle, F.H., Lovley, D.R., 1992. Competitive-exclusion of sulfate reduction by fe(iii)-reducing bacteria-a mechanism for producing discrete zones of high- iron ground-water. Ground Water 30(1), 29-36.

Charette, M.A., Buesseler, K.O., Andrews, J.E., 2001. Utility of radium isotopes for evaluating the input and transport of groundwater-derived nitrogen to a Cape Cod estuary. Limnology and Oceanography 46(2), 465-470.

Charette, M.A., Sholkovitz, E.R., 2002. Oxidative precipitation of groundwater-derived ferrous iron in the subterranean estuary of a coastal bay. Geophysical Research Letters 29(10) art. no. 1444.

Christensen, T.H., et al., 2000. Characterization of redox conditions in groundwater contaminant plumes. Journal of Contaminant Hydrology 45(3-4), 165-241.

Christensen, T.H., et al., 2001. Biogeochemistry of landfill leachate plumes. Applied Geochemistry 16(7-8), 659-718.

Church, T.M., 1996. An underground route for the water cycle. Nature 380(6575), 579-580.

Conley, D.J., 2000. Biogeochemical nutrient cycles and nutrient management strategies. Hydrobiologia 410, 87-96.

Cooper, H.H., 1959. A hypothesis concerning the dynamic balance of fresh water and salt water in a coastal aquifer. Journal of Geophysical Research 64, 461-467.

Corbett, D.R., et al., 1999. Patterns of groundwater discharge into Florida Bay. Limnology and Oceanography 44(4), 1045-1055.

Corbett, D.R., Dillon, K., Burnett, W., Chanton, J., 2000. Estimating the groundwater contribution into Florida Bay via natural tracers, Rn-222 and CH4. Limnology and Oceanography 45(7), 1546- 1557. 
D’Elia, C.F.D., Webb, K.L., Porter, J.W., 1981. Nitrate-rich groundwater inputs to discovery Bay, Jamaica: a significant source of $\mathrm{N}$ to local coral reefs? Bulletin of Marine Science 31, 903-910.

Desimone, L.A., Howes, B.L., 1996. Denitrification and nitrogen transport in a coastal aquifer receiving wastewater discharge. Environmental Science and Technology 30, 1152-1162.

Dillon, P.J., Kirchner, W.B., 1975. The effects of geology and land use on the export of phosphorus from watersheds. Water Research 9, 135-148.

Engesgaard, P., Kipp, K.L., 1992. A geochemical transport model for redox-controlled movement of mineral fronts in groundwater flow systems: a case of nitrate removal by oxidation of pyrite. Water Resources Research 28, 2829-2843.

Fetter, C.W., 1994. Applied Hydrogeology, vol. 598. Prentice Hall, New Jersey.

Gallagher, D.L., Dietrich, A.M., Reay, W.G., Hayes, M.C., Simmons, G.M., 1996. Ground water discharge of agricultural pesticides and nutrients to estuarine surface water. Ground Water Monitoring and Remediation 16(1), 118-129.

Garrels, R.M., Mackenzie, F.T., 1971. Evolution of Sedimentary Rocks,.

Garrison, G.H., Glenn, C.R., McMurty, G.M., 2003. Measurement of submarine groundwater discharge in Kahana Bay, O'ahu, Hawai'i. Limnology and Oceanography 48, 920-928.

Giblin, A.E., Gaines, A.G., 1990. Nitrogen inputs to a marine embayment-the importance of groundwater. Biogeochemistry 10(3), 309-328.

Gobler, C.J., Sanudo-Wilhelmy, S.A., 2001. Temporal variability of groundwater seepage and brown tide blooms in a Long Island embayment. Marine Ecology-Progress Series 217, 299-309.

Gomis-Yagues, V., Boluda-Botella, N., Ruiz-Bevia, F., 2000. Gypsum precipitation/dissolution as an explanation of the decrease of sulphate concentration during seawater intrusion. Journal of Hydrology 228(1-2), 48-55.

Gramling, C.M., McCorkle, D.C., Mulligan, A.E., Woods, T.L., 2003. A carbon isotope method to quantify groundwater discharge at the land-sea interface. Limnology and Oceanography 48, 957-970.

Griffioen, J., 1994. Uptake of phosphate by iron hydroxides during seepage in relation to development of groundwater composition in coastal areas. Environmental Science and Technology 28, 675-681.

Grobler, D.C., Silberbauer, M.J., 1985. The combined effect of geology, phosphate sources and runoff on phosphate export from drainage basins. Water Research 19, 975-981.

Groen, J., Velstra, J., Meesters, A., 2000. Salinization processes in paleowaters in coastal sediments of Suriname: evidence from delta Cl-37 analysis and diffusion modelling. Journal of Hydrology 234(1-2), 1-20.

Groen, K., 2002. The effects of transgressions and regressions on coastal and offshore groundwater, Vrije Universiteit, Amsterdam, pp. 192.

Hansen, L.K., Jakobsen, R., Postma, D., 2001. Methanogenesis in a shallow sandy aquifer, Romo, Denmark. Geochimica et Cosmochimica Acta 65(17), 2925-2935.
Hartog, N., van Bergen, P.F., de Leeuw, J.W., Griffioen, J., 2004. Reactivity of organic matter in aquifer sediments: geological and geochemical controls. Geochimica Et Cosmochimica Acta, $68,1281-1292$.

Hartog, N., Griffioen, J., van der Weijden, C.H., 2002. Distribution and reactivity of $\mathrm{O} 2$-reducing components in sediments from a layered aquifer. Environmental Science and Technology 36, 2338-2344.

Herrera-Silveira, J.A., Comin, F.A., 1995. Nutrient fluxes in a tropical coastal lagoon. Ophelia 42, 127-146.

Holtan-Hartwig, L., Dorsch, P., Bakken, L.R., 2002. Low temperature control of soil denitrifying communities: kinetics of $\mathrm{N} 2 \mathrm{O}$ production and reduction. Soil Biology \& Biochemistry 34(11), 1797-1806.

Howarth, R.W., 1988. Nutrient limitation of net primary production in marine ecosystems. Annual Review of Ecology and Systematics 19, 89-110.

Howarth, R.W., Jensen, H.S., Marino, R., Postma, H., 1995. Transport to and processing of $\mathrm{P}$ in near-shore and oceanic waters. In: Tiessen, H., (Ed.), Phosphorus in the Global Environment. Transfers, cycles and Management. SCOPE, vol. 54. Wiley, New York, pp. 323-345.

Hunter, K.S., Wang, Y.F., Van Cappellen, P., 1998. Kinetic modeling of microbially-driven redox chemistry of subsurface environments: coupling transport, microbial metabolism and geochemistry. Journal of Hydrology 209(1-4), 53-80.

Hussain, N., Church, T.M., Kim, G., 1999. Use of Rn-222 and Ra226 to trace groundwater discharge into the Chesapeake Bay. Marine Chemistry 65(1-2), 127-134.

Jakobsen, R., Postma, D., 1999. Redox zoning, rates of sulfate reduction and interactions with Fe-reduction and methanogenesis in a shallow sandy aquifer, Romo, Denmark. Geochimica et Cosmochimica Acta 63(1), 137-151.

Johannes, R.E., 1980. The ecological significance of the submarine discharge of groundwater. Marine Ecology-Progress Series 3, $365-373$.

Johannes, R.E., Hearn, C.J., 1985. The effect of subsurface groundwater discharge on nutrient and salinity regimes in a coastal lagoon off Perth, West Australia. Estuarine Coastal and Shelf Science 21, 789-800.

Jordan, T.E., Correll, D.L., Weller, D.E., 1997. Relating nutrient discharges from watersheds to land use and streamflow variability. Water Resources Research 33(11), 2579-2590.

Kalbitz, K., Solinger, S., Park, J.H., Michalzik, B., Matzner, E., 2000. Controls on the dynamics of dissolved organic matter in soils: A review. Soil Science 165(4), 277-304.

Kempe, S., 1984. Sinks of the anthropogenically enhanced carbon cycle in surface fresh waters. Journal of Geophysical Research 89, 4657-4676.

Kim, G., Hwang, D.W., Yang, H.S., Jung, D.J., 2004. Tracing the source of excess nutrients using radium isotopes in the 'red tide' areas of the South Sea of Korea. Limnology and Oceanography submitted for publication.

Kooi, H., Groen, J., 2001. Offshore continuation of coastal groundwater systems; predictions using sharp-interface 
approximations and variable-density flow modelling. Journal of Hydrology 246(1-4), 19-35.

Kooi, H., Groen, J., Leijnse, A., 2000. Modes of seawater intrusion during transgressions. Water Resources Research 36(12), 3581-3589.

Krest, J.M., Harvey, J.W., 2003. Using natural distributions of short-lived radium isotopes to quantify groundwater discharge and recharge. Limnology and Oceanography 48, 290-298.

Krest, J.M., Moore, W.S., Gardner, L.R., 2000. Marsh nutrient export supplied by groundwater discharge: Evidence from radium measurements. Global Biogeochemical Cycles 14, 167-176.

Krest, J.M., Moore, W.S., Rama, 1999. 226Ra and 228Ra in the mixing zones of the Mississippi and Atchafalaya Rivers: indicators of groundwater input. Marine Chemistry 64(3), $129-152$.

Lapointe, B.E., 1997. Nutrient thresholds for bottom-up control of macroalgal blooms on coral reefs in Jamaica and southeast Florida. Limnology and Oceanography 42(5), 1119-1131.

Lapointe, B.E., O’Connell, J.D., Garrett, G.S., 1990. Nutrient couplings, between on-site sewage disposal systems, groundwaters, nearshore surface waters of the Florida Keys. Biogeochemistry 10, 289-307.

Lee, D.R., 1977. A device for measuring seepage flux in lakes and estuaries. Limnology and Oceanography 22, 140-147.

Lewis, J.B., 1987. Measurements of groundwater seepage flux into a coral reef: spatial and temporal variations. Limnology and Oceanography 32, 1165-1169.

Li, L., Barry, D.A., Stagnitti, F., Parlange, J.Y., 1999. Submarine groundwater discharge and associated chemical input to a coastal sea. Water Resources Research 35(11), 3253-3259.

Lovely, D.R., Chapelle, F.H., 1995. Deep subsurface microbial processes. Reviews of Geophysics 33, 365-381.

Mackenzie, F.T., Ver, L.M., Sabine, C., Lane, M., Lerman, A., 1993. C, N, P, S Global biogeochemical cycles and modeling of global change. In: Wollast, R., Mackenzie, F.T., Chou, L. (Eds.), Interactions of C, N, P and S Biogeochemical cycles and globalchange, Springer, Berlin.

Mackenzie, F.T., Vera, L.M., Lerman, A., 2002. Century-scale nitrogen and phosphorus controls of the carbon cycle. Chemical Geology 190(1-4), 13-32.

Matson, E.A., 1993. Nutrient flux through soils and aquifers to the coastal zone of guam (Mariana Islands). Limnology and Oceanography 38(2), 361-371.

McDowell, W.H., 2003. Dissolved organic matter in soils-future directions and unanswered questions. Geoderma 113(3-4), $179-186$

Meile, C., Van Cappellen, P., 2003. Global estimates of enhanced solute transport in marine sediments. Limnology and Oceanography $48,777-786$.

Meybeck, M., 1982. Carbon, nitrogen, and phosphorus transport by world rivers. American Journal of Science 282, 401-450.

Meybeck, M., 1993. C, N, P and S in rivers: from sources to global inputs. In: Wollast, R., Mackenzie, F.L., Chou, L. (Eds.), Interactions of C, N, P and S Biogeochemical Cycles and Global Change. NATO ASI, Springer, Berlin, pp. 163-193.
Middelburg, J.J., Soetaert, K., Herman, P.M.J., Heip, C.H.R., 1996. Denitrification in marine sediments: a model study. Global Biogeochemical Cycles 10, 661-673.

Moore, W.S., 1996. Large groundwater inputs to coastal waters revealed by Ra-226 enrichments. Nature 380(6575), 612-614.

Moore, W.S., 1999. The subterranean estuary: a reaction zone of ground water and sea water. Marine Chemistry 65(1-2), $111-125$.

Moore, W.S., Krest, J., Taylor, G., Roggenstein, E., Joye, S., Lee, R., 2002. Thermal evidence of water through a coastal aquifer: Implications for nutrient fluxes. Geophysical Research Letters 29(14):art. no, -1704.

Moore, W.S., Shaw, T.J., 1998. Chemical signals from submarine fluid advection onto the continental shelf. Journal of Geophysical Research-Oceans 103(C10), 21543-21552.

Murphy, E.M., Schramke, J.A., 1998. Estimation of microbial respiration rates in groundwater by geochemical modeling constrained with stable isotopes. Geochimica et Cosmochimica Acta 62(21-22), 3395-3406.

Nixon, S.W., Kelly, J.R., Furnas, B.N., Oviatt, C.A., Hale, S.S., 1980. In: Tenore, K.R., Coull, B.C. (Eds.), Phosphorus regeneration and the metabolism of coastal marine bottom communities, Marine Benthic Dynamics. University of South Carolina, pp. 219-242.

Nolan, B.T., Stoner, J.D., 1995. Nutrients in groundwaters of the conterminous United States 1992-1995. Environmental Science and Technology 34(7), 1156-1165.

Nowicki, B.L., Requintina, E., Van Keuren, D., Portnoy, J., 1999. The role of sediment denitrification in reducing groundwaterderived nitrate inputs to Nauset Marsh estuary, Cape Cod, Massachusetts. Estuaries 22(2A), 245-259.

Nyvang, V., 2003. Redox processes at the salt-/freshwater interface in an anaerobic aquifer. PhD-Thesis. Technical University of Denmark.

Oberdorfer, J.A., Valentino, M.A., Smith, S.V., 1990. Groundwater Contribution to the Nutrient Budget of Tomales Bay, California. Biogeochemistry 10(3), 199-216.

Pabich, W.J., Valiela, I., Hemond, H.F., 2001. Relationship between DOC concentration and vadose zone thickness and depth below water table in groundwater of Cape Cod, USA. Biogeochemistry 55(3), 247-268.

Paerl, H.W., 1997. Coastal eutrophication and harmful algal blooms: importance of atmospheric deposition and groundwater as 'new' nitrogen and other nutrient sources. Limnology and Oceanography 42, 1154-1165.

Portnoy, J.W., Nowicki, B.L., Roman, C.T., Urish, D.W., 1998. The discharge of nitrate-contaminated groundwater from developed shoreline to marsh-fringed estuary. Water Resources Research 34(11), 3095-3104.

Postma, D., Boesen, C., Kristiansen, H., Larsen, F., 1991. Nitrate reduction in an unconfined sandy aquifer: water chemistry, reduction processes and geochemical modeling. Water Resources Research 27, 2027-2045.

Qualls, R.G., Richardson, C.J., 2003. Factors controlling concentration, export, and decomposition of dissolved organic 
nutrients in the Everglades of Florida. Biogeochemistry 62(2), 197-229.

Rabouille, C., Mackenzie, F.T., Ver, L.M., 2001. Influence of the human perturbation on carbon, nitrogen, and oxygen biogeochemical cycles in the global coastal ocean. Geochimica Et Cosmochimica Acta 65(21), 3615-3641.

Reilly, T.E., Goodman, A.S., 1985. Quantitative analysis of saltwater-freshwater relationships in groundwater systems-a historical perspective. Journal of Hydrology 80, 125-160.

Richards, J.E., Webster, C.P., 1999. Denitrification in the subsoil of the Broadbalk Continuous Wheat Experiment. Soil Biology and Biochemistry 31(5), 747-755.

Riedl, R., Huang, N., Machan, R., 1972. The subtidal pump: a mechanism of interstitial water exchange by wave action. Marine Biology 13, 210-221.

Robertson, W.D., 1995. Development of steady-state phosphate concentrations in septic system plumes. Journal of Contaminant Hydrology 19(4), 289-305.

Robinson, M., Gallagher, D., Reay, W., 1998. Field observations of tidal and seasonal variations in ground water discharge to tidal estuarine surface water. Ground Water Monitoring and Remediation 18(1), 83-92.

Rutkowski, C.M., Burnett, W.C., Iverson, R.L., Chanton, J.P., 1999. The effect of groundwater seepage on nutrient delivery and seagrass distribution in the northeastern Gulf of Mexico. Estuaries 22(4), 1033-1040.

Ruttenberg, K.C., 1993. Reassessment of the oceanic residence time of phosphorus. Chemical Geology 107, 405-409.

Sanford, W.E., Konikow, L.F., 1989. Simulation of calcite dissolution and porosity changes in saltwater mixing zones in coastal aquifers. Water Resources Research 25, 655-667.

Schippers, A., Jorgensen, B.B., 2002. Biogeochemistry of pyrite and iron sulfide oxidation in marine sediments. Geochimica Et Cosmochimica Acta 66(1), 85-92.

Seitzinger, S.P., Gardner, L.R., Spratt, A.K., 1991. The effect of salinity on ammonium sorption in aquatic sediments: implications for benthic nutrient recycling. Estuaries 14, $167-174$.

Seitzinger, S.P., et al., 2002. Global patterns of dissolved inorganic and particulate nitrogen inputs to coastal systems: Recent conditions and future projections. Estuaries 25(4B), 640-655.

Seitzinger, S.P., Kroeze, C., 1998. Global distribution of nitrous oxide production and $\mathrm{N}$ inputs in freshwater and coastal marine ecosystems. Global Biogeochemical Cycles 12, 93-113.

Sewell, P.L., 1982. Urban groundwater as a possible nutrient source for an estuarine benthic algal bloom. Estuarine Coastal and Shelf Science 15, 569-576.

Shaw, T.J., Moore, W.S., Kloepfer, J., Sochaski, M.A., 1998. The flux of barium to the coastal waters of the southeastern USA: the importance of submarine groundwater discharge. Geochimica Et Cosmochimica Acta 62, 3047-3054.

Simmons, G.M., 1992. Importance of submarine groundwater discharge (Sgwd) and seawater cycling to material flux across sediment water interfaces in marine environments. Marine Ecology-Progress Series 84(2), 173-184.
Simmons, J.A.K., Lyons, W.B., 1994. The groundwater flux of nitrogen and phosphorus to Bermuda's coastal waters. Water Research Bullettin 30, 983-991.

Slater, J.M., Capone, D.G., 1989. Denitrification in aquifer soils and nearshore marine sediments influenced by groundwater nitrate. Applied and Environmental Microbiology 53, 1292-1297.

Smith, S.V., et al., 2003. Humans, hydrology and the distribution of inorganic nutrient loading to the ocean. Bio Science 53, $235-245$.

Stalnacke, P., Grimvall, A., Libiseller, C., Laznik, M., Kokorite, I., 2003. Trends in nutrient concentrations in Latvian rivers and the response to the dramatic change in agriculture. Journal of Hydrology, 283, 184-205.

Starr, R.C., Gillham, R.W., 1993. Denitrification and organic carbon availability in two aquifers. Ground Water 31(6), 934-947.

Suzumura, M., Ueda, S., Sumi, E., 2000. Control of phosphate concentration through adsorption and desorption processes in groundwater and seawater mixing at sandy beaches in Tokyo Bay, Japan. Journal of Oceanography 56, 667-673.

Swarzenski, P.W., Reich, C.D., Spechler, R.M., Kindinger, J.L., Moore, W.S., 2001. Using multiple geochemical tracers to characterize the hydrogeology of the submarine spring off Crescent Beach, F lorida. Chemical Geology 179(1-4), $187-202$.

Taniguchi, M., 2002. Tidal effects on submarine groundwater discharge into the ocean. Geophysical Research Letters 29(12) art. no. 1561.

Taniguchi, M., Burnett, W.C., Cable, J.E., Turner, J.V., 2002. Investigation of submarine groundwater discharge. Hydrological Processes 16(11), 2115-2129.

Taniguchi, M., Fukuo, Y., 1993. Continuous measurements of groundwater seepage using an automatic seepage meter. Ground Water 31, 675-679.

Tesoriero, A.J., Liebscher, H., Cox, S.E., 2000. Mechanism and rate of denitrification in an agricultural watershed: electron and mass balance along groundwater flow paths. Water Resources Research 36, 1545-1559.

Tiessen, H., 1995. Phosphorus in the global environment, Transfers, Cycles and Management. SCOPE, vol. 54. Wiley, New York, pp. 462.

Top, Z., Brand, L.E., Corbett, R.D., Burnett, W., Chanton, J., 2001. Helium and radon as tracers of groundwater input into Florida Bay. Journal of Coastal Research 17(4), 859-868.

Toth, J., 1963. A theoretical analysis of groundwater flow in small drainage basins. Journal of Geophysical Research 68, $4795-4812$.

Tyrrell, T., 1999. The relative influences of nitrogen and phosphorus on oceanic primary production. Nature 400, $525-531$.

Uchiyama, Y., Nadaoka, K., Rolke, P., Adachi, K., Yagi, H., 2000. Submarine groundwater discharge into the sea and associated nutrient transport in a sandy beach. Water Resources Research 36(6), 1467-1479.

Ueda, S., Chun-Sim, U.G., Suzumura, M., Sumi, E., 2003. Denitrification in a seashore sandy deposit influenced by groundwater discharge. Biogeochemistry 63(2-5), 187. 
United States Environmental Protection Agency, US. 1995. Drinking Water Regulations and Health Advisories, Office of Water, Washington, DC

Valiela, I., et al., 1990. Transport of groundwater-borne nutrients from watersheds and their effects on coastal waters. Biogeochemistry 10(3), 177-197.

Valiela, I., et al., 1992. Couplings of watersheds and coastal waterssources and consequences of nutrient enrichment in Waquoit Bay. Massachusetts. Estuaries 15(4), 443-457.

Van Cappellen, P., Ingall, E.D., 1994. Benthic phosphorus regeneration, net primary production, and ocean anoxia: a model of the coupled marine biogeochemical cycles of carbon and phosphorus. Paleoceanography(9), 677-692.

Van der Molen, D.T., Breeuwsma, A., Boers, P.C.M., 1998. Agricultural nutrient losses to surface water in the Netherlands: impact, strategies, and perspectives. Journal of Environmental Quality 27(1), 4-11.

Veldhuis, M.J.W., Colijn, F., Admiraal, W., 1991. Phosphate Utilization in Phaeocystis-Pouchetii (Haptophyceae). Marine EcologyPubblicazioni Della Stazione Zoologica Di Napoli I 12(1), 53-62.

Ver, L.M.B., Mackenzie, F.T., Lerman, A., 1999a. Biogeochemical responses of the carbon cycle to natural and human perturbations: past, present, and future. American Journal of Science 299, $762-801$.

Ver, L.M.B., Mackenzie, F.T., Lerman, A., 1999b. Carbon cycle in the coastal zone: effects of global perturbations and change in the past three centuries. Chemical Geology 159(1-4), 283-304.

Weiskel, P.K., Howes, B.L., 1992. Differential transport of sewage-derived Nitrogen and Phosphorus through a coastal watershed. Environmental Science and Technology 26, $352-360$.

Wilhelm, S.R., Schiff, S.L., Cherry, J.A., 1994. Biogeochemical evolution of domestic waste water in septic systems: 1 Conceptual model. Ground Water 32, 905-916.

Younger, P.L., 1996. Submarine groundwater discharge. Nature 382, 121-122.

Zanini, L., Robertson, W.D., Ptacek, C.J., Schiff, S.L., Mayer, T., 1998. Phosphorus characterization in sediments impacted by septic effluent at four sites in central Canada. Journal of Contaminant Hydrology 33(3-4), 405-429.

Zektser, I.S., Loaiciga, H.A., 1993. Groundwater fluxes in the global hydrologic-cycle-past, present and future. Journal of Hydrology 144(1-4), 405-427. 